Article

\title{
Impact of SARS-CoV-2 on Ambient Air Quality in Northwest China (NWC)
}

\author{
Shah Zaib ${ }^{1} \mathbb{D}$, Jianjiang Lu ${ }^{1, *}$, Muhammad Zeeshaan Shahid ${ }^{2}$, Sunny Ahmar ${ }^{3}$ and Imran Shahid ${ }^{4}$ \\ 1 Key Laboratory of Environmental Monitoring and Pollution Control of Xinjiang Bingtuan, \\ School of Chemistry and Chemical Engineering, Shihezi University, Shihezi 832003, China; \\ szaib716@gmail.com \\ 2 Ministry of Public Health, Al Rumaila, Doha P.O. Box 42, Qatar; muhammad.shahid.1@kaust.edu.sa \\ 3 Institute of Biological Sciences, University of Talca, 1 Poniente 1141, Talca 3460000, Chile; \\ sunny.ahmar@yahoo.com \\ 4 Environmental Science Center, Qatar University, Doha P.O. Box 2713, Qatar; ishahid@qu.edu.qa \\ * Correspondence: lujianjiang2015@163.com
}

Citation: Zaib, S.; Lu, J.; Shahid,

M.Z.; Ahmar, S.; Shahid, I. Impact of SARS-CoV-2 on Ambient Air Quality in Northwest China (NWC).

Atmosphere 2021, 12, 518.

https://doi.org/10.3390/

atmos12040518

Academic Editor: Mizuo Kajino

Received: 19 March 2021

Accepted: 16 April 2021

Published: 19 April 2021

Publisher's Note: MDPI stays neutral with regard to jurisdictional claims in published maps and institutional affiliations.

Copyright: (C) 2021 by the authors. Licensee MDPI, Basel, Switzerland. This article is an open access article distributed under the terms and conditions of the Creative Commons Attribution (CC BY) license (https:// creativecommons.org/licenses/by/ $4.0 /)$.

\begin{abstract}
SARS-CoV-2 was discovered in Wuhan (Hubei) in late 2019 and covered the globe by March 2020. To prevent the spread of the SARS-CoV-2 outbreak, China imposed a countrywide lockdown that significantly improved the air quality. To investigate the collective effect of SARS-CoV-2 on air quality, we analyzed the ambient air quality in five provinces of northwest China (NWC): Shaanxi (SN), Xinjiang (XJ), Gansu (GS), Ningxia (NX) and Qinghai (QH), from January 2019 to December 2020. For this purpose, fine particulate matter $\left(\mathrm{PM}_{2.5}\right)$, coarse particulate matter $\left(\mathrm{PM}_{10}\right)$, sulfur dioxide $\left(\mathrm{SO}_{2}\right)$, nitrogen dioxide $\left(\mathrm{NO}_{2}\right)$, carbon monoxide $(\mathrm{CO})$, and ozone $\left(\mathrm{O}_{3}\right)$ were obtained from the China National Environmental Monitoring Center (CNEMC). In 2020, $\mathrm{PM}_{2.5}, \mathrm{PM}_{10}, \mathrm{SO}_{2}, \mathrm{NO}_{2}$, $\mathrm{CO}$, and $\mathrm{O}_{3}$ improved by $2.72 \%, 5.31 \%, 7.93 \%, 8.40 \%, 8.47 \%$, and $2.15 \%$, respectively, as compared with 2019. The $\mathrm{PM}_{2.5}$ failed to comply in SN and XJ; $\mathrm{PM}_{10}$ failed to comply in SN, XJ, and NX with CAAQS Grade II standards $\left(35 \mu \mathrm{g} / \mathrm{m}^{3}, 70 \mu \mathrm{g} / \mathrm{m}^{3}\right.$, annual mean). In a seasonal variation, all the pollutants experienced significant spatial and temporal distribution, e.g., highest in winter and lowest in summer, except $\mathrm{O}_{3}$. Moreover, the average air quality index (AQI) improved by $4.70 \%$, with the highest improvement in SN followed by QH, GS, XJ, and NX. AQI improved in all seasons; significant improvement occurred in winter (December to February) and spring (March to May) when lockdowns, industrial closure etc. were at their peak. The proportion of air quality Class I improved by $32.14 \%$, and the number of days with $\mathrm{PM}_{2.5}, \mathrm{SO}_{2}$, and $\mathrm{NO}_{2}$ as primary pollutants decreased while they increased for $\mathrm{PM}_{10}, \mathrm{CO}$, and $\mathrm{O}_{3}$ in 2020. This study indicates a significant association between air quality improvement and the prevalence of SARS-CoV-2 in 2020.
\end{abstract}

Keywords: SARS-CoV-2; northwest China; AQI; primary pollutant; Pearson correlation

\section{Introduction}

In recent years, unprecedented industrial activity, urbanization, and motorization have jeopardized the air quality in northwest China (NWC) [1-4]. Multiple studies observed higher pollution levels in NWC due to increased industry, coal consumption, biomass burning, civil heating, power generation, urbanization, and natural sources [5-13]. Deteriorated air quality has attracted the attention of the scientific community because of its detrimental health effects [14-19]. Fine particulate matter $\left(\mathrm{PM}_{2.5}\right)$ is a major pollutant, ranked as the primary leading risk factor for disease in China, with more than 1.1 million premature deaths due to stroke, ischemic heart disease (IHD), chronic obstructive pulmonary disease (COPD), lung cancer, and lower respiratory infections [20-22].

The SARS-CoV-2 also known as "COVID-19" was first discovered in December 2019 in Wuhan, a city in the Hubei province of China [23-25]. This deadly virus covered the globe within two months, and the World Health Organization (WHO) declared a pandemic 
on 11 March 2020 (WHO 2020). The common symptoms of COVID-19 include fever, dry cough, tiredness, and shortness of breath. In contrast, severe symptoms include a runny nose, sore throat, chills, muscle aches, headache, diarrhea, nausea, chest pain, breathing difficulties, and organ failure [26,27]. So far, COVID-19 has infected more than 133.10 million people and killed 2.90 million people worldwide (https:/ / ourworldindata.org/ covid-cases/, accessed on 14 April 2021).

To slow down the spread of the COVID-19 outbreak, China imposed a nationwide lockdown, e.g., travel restrictions, industrial closure etc., on 23 January 2020, starting from Wuhan (Hubei) [28]. Later on, the lockdown spread all over mainland China with a significant spatial and temporal variation. Multiple studies observed a reduction in anthropogenic emission and an improvement in the air quality index (AQI) due to epidemic prevention and control measures (lockdowns, travel restrictions, industrial closure etc.) throughout the globe [29-33]. Reference [34] observed that the average concentration of nitrogen dioxide $\left(\mathrm{NO}_{2}\right), \mathrm{PM}_{2.5}$, and coarse particulate matter $\left(\mathrm{PM}_{10}\right)$ decreased by $27.0 \%$, $10.5 \%$, and $21.4 \%$, respectively, during lockdown (January to April) in China. Similarly, [35] observed short-term pollution reduction due to industrial closure, movement restrictions, and traffic stagnation in China. To further strengthen the claim that lockdowns improved air quality, [36] concluded that the AQI improved by 19.84 points in locked down cities and by 6.34 points in cities without formal lockdown. Reference [30] concluded that in Anhui province (Anqing, Hieifi, and Shuzou) the average concentrations of $\mathrm{PM}_{2.5}$, $\mathrm{PM}_{10}$, sulfur dioxide $\left(\mathrm{SO}_{2}\right)$, carbon monoxide (CO), and $\mathrm{NO}_{2}$ decreased by $46.5 \%, 48.9 \%$, $52.5 \%, 36.2 \%$, and $52.8 \%$, respectively, during the lockdown. Similarly, Hubei province (Wuhan, Jingmen, and Enshi) experienced 30.1\%, 40.5\%, 61.4\%, 33.4\%, and 27.9\% reduction in $\mathrm{PM}_{2.5}, \mathrm{PM}_{10}, \mathrm{NO}_{2}, \mathrm{SO}_{2}$, and $\mathrm{CO}$, respectively, during lockdown months (January 2020 to March 2020) [27]. Another study in Wuhan observed that the AQI, $\mathrm{PM}_{2.5}$, and $\mathrm{NO}_{2}$ decreased by $47.5 \%, 36.9 \%$, and $53.3 \%$, respectively, during lockdown [37]. Just like other areas, Shanghai also experienced a 9\%, 77\%, 31.3\%, 60.4\%, and 3\% decrease in $\mathrm{PM}_{2.5}, \mathrm{PM}_{10}$, $\mathrm{SO}_{2}, \mathrm{NO}_{2}$, and $\mathrm{CO}$, respectively, during lockdown months [38].

During the lockdown period (January 2020 to March 2020), most of the studies focused on air quality assessment in central China and nearby areas while ignoring rapidly developing areas of NWC [27,30,34-38]. However, very few studies assessed the air quality in northwest China (the industrial and manufacturing hub of China) to evaluate the influence of the COVID-19 outbreak and associated lockdowns on air quality. A study conducted by He et al. [31] observed that the AQI $\left(\mathrm{SO}_{2}, \mathrm{PM}_{2.5}, \mathrm{PM}_{10}, \mathrm{NO}_{2}\right.$, and $\left.\mathrm{CO}\right)$ improved by $7.8 \%$ $(6.76 \%, 5.93 \%, 13.66 \%, 24.67 \%$, and $4.58 \%)$ in Lanzhou (Gansu province) during the lockdown. Similarly, [39] observed that $\mathrm{PM}_{1}$ decreased by $50 \%$ during the Lanzhou lockdown period (January to March). Depending on the spread of the viral outbreak, lockdowns, travel restrictions, etc. were extended and re-imposed in some areas, e.g., Kashgar city (October 2020). No study has extensively analyzed the influence of the viral outbreak and lockdowns on air quality in northwest China.

In this study, we assessed the spatial and temporal variation of air pollution in 53 cities of NWC. We examined six criteria pollutants $\left(\mathrm{PM}_{2.5}, \mathrm{PM}_{10}, \mathrm{SO}_{2}, \mathrm{NO}_{2}, \mathrm{CO}\right.$, and $\left.\mathrm{O}_{3}\right)$, the air quality index (AQI), the proportion of $\mathrm{AQI}$ classes, and major pollutants etc. for a period of two years (January 2019 to December 2020) to illustrate the impact of SARS-CoV-2 and associated lockdowns on the spatial and temporal distribution of air pollution in NWC. We believe this is the first study focusing on the long-term impact of the COVID-19 outbreak on air quality in 53 cities of NWC and is of considerable significance to environmental protection and human health.

\section{Materials and Methods}

\subsection{Site Selection}

Northwest China (NWC) is a mixture of agricultural land, deserts, mountains, industrial complexes, significant mineral reserves, and degraded air quality. We analyzed the ambient air quality in 53 cities locatecd in five provinces (Shaanxi (SN), Xinjiang (XJ), 
Gansu (GS), Ningxia (NX), and Qinghai (QH)) of NWC from January 2019 to December 2020 to understand the spatial temporal variation across NWC better. SN includes 10 cities (Ankang, Baoji, Hanzhong, Shanglou, Tongcuan, Weinan, Xian, Xianyang, Yanna, Yulin), and XJ includes 16 cities (Aksu, Altay, Bortala, Crete, Changji, Hami, Hotan, Ili, Karamay, Korla, Kashgar, Shihezi, Tacheng, Turpan, Urumqi, Wujiaqu). Similarly, GS includes 14 cities (Dingxi, Gannn, Jiayuguan, Jinchang, Jiuquan, Lanzhou, Linxia, Longnan, Pinglian, Qingyang, Silver city, Tianshui, Wuwei, Zhangye), and NX includes five cities (Guyuan, Shizuishan, Yinchuan, Wuzhong, Zhongwei). QH includes eight cities (Guolou, Haibei, Haidong, Hainan, Haixi, Huangnan, Xinning, Yushu). A location map of the cities under observation is shown in Figure 1.

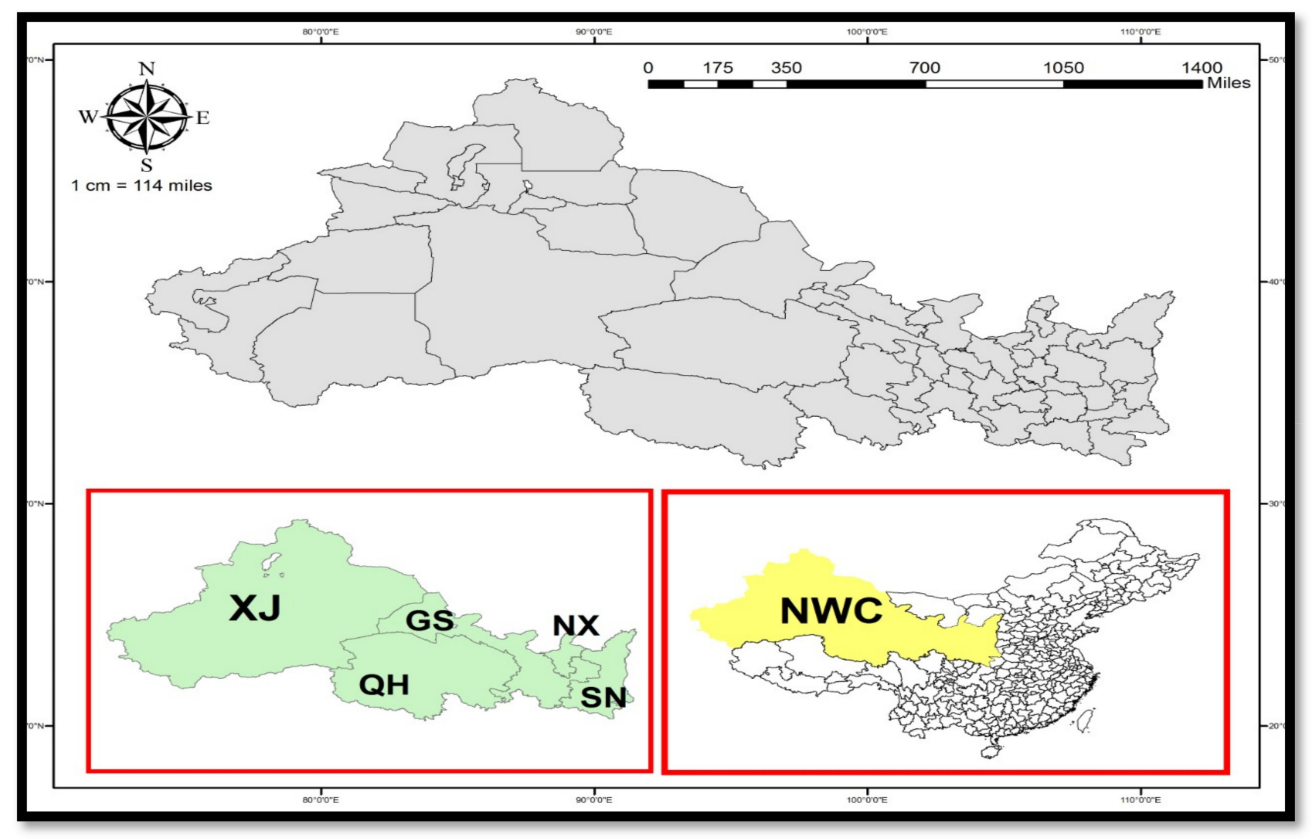

Figure 1. Location map of five provinces (Shaanxi (SN), Xinjiang (XJ), Gansu (GS), Ningxia (NX), Qinghai $(\mathrm{QH})$ ) in Northwest China (NWC).

\subsection{Data Collection}

The hourly concentration of six criteria pollutants $\left(\mathrm{PM}_{2.5}, \mathrm{PM}_{10}, \mathrm{SO}_{2}, \mathrm{NO}_{2}, \mathrm{CO}\right.$, and $\mathrm{O}_{3}$ ) in NWC was obtained from the China National Environmental Monitoring Center (CNEMC) for a period of two years (2019-2020). The online data-sharing platform had installed hundreds of ambient air monitoring stations, covering both urban and rural areas in 337 cities of China, and published information according to the Technical Guideline on Environmental Monitoring Quality Management (HJ 630-2011).

\subsection{Air Quality Index (AQI)}

The air quality index (AQI) is a color-coded scale that simplifies different pollutants' concentrations into a single numerical value to reflect overall air quality, health effects, sensitive groups, and required precautionary measures. The AQI includes 24 -h average measurements of $\mathrm{NO}_{2}, \mathrm{SO}_{2}, \mathrm{CO}, \mathrm{PM} 2.5, \mathrm{PM} 10$, and 8-h average concentrations of $\mathrm{O}_{3}[12,13,40]$. When the AQI is higher than 50, the highest Individual air quality index (IAQI) is considered a primary pollutant for that given day [13,30,41-43]. The individual air quality index (IAQI) for six criteria pollutants is determined by using Equation (1), and the overall AQI is calculated based on the highest IAQI by using Equation (2) according to the instruction given in the technical regulation on ambient air quality index (on trial) (HJ-633-2012).

$$
\mathrm{IAQI}=\mathrm{I}_{\text {high }}-\mathrm{I}_{\text {low }} / \mathrm{C}_{\text {high }}-\mathrm{C}_{\text {low }} *\left(\mathrm{C}_{\mathrm{P}}-\mathrm{C}_{\text {low }}\right)+\mathrm{I}_{\text {low }}
$$


$I A Q I_{P}=$ Individual sub air quality index of the pollutant $\mathrm{p}$

$C_{P}=$ concentration of the pollutant $\mathrm{p}$

$C_{\text {high }}=$ concentration breakpoint that is $\geq C_{p}$

$C_{\text {low }}=$ concentration breakpoint that is $\leq C_{p}$

$I_{\text {high }}=$ index breakpoint corresponding to $C_{\text {high }}$

$I_{\text {low }}=$ index breakpoint corresponding to $C_{\text {low }}$

$$
\mathrm{AQI}=\max \left(\mathrm{I}_{1}, \mathrm{I}_{2}, \ldots, \mathrm{In}\right)
$$

$A Q I$ has the following six categories: Class I; 0-50 (green), good; Class II: 51-100 (yellow), moderate; Class III: 101-150 (orange), unhealthy for sensitive groups; Class IV: 151-200 (red), unhealthy; Class V: 201-300 (purple), very unhealthy; Class VI: 300-500 (maroon), hazardous.

\subsection{Quality Assurance and Quality Control (QAEAR)}

Quality assurance and control procedures for ambient air quality data were strictly by Chinese Ambient Air Quality Standards (CAAQS) (GB 3095 2012). The daily average value was calculated when we had valid data for more than $16 \mathrm{~h}$ of that day (except for $\mathrm{O}_{3}$, minimum 6-h values for 8-h $\mathrm{O}_{3}$ value). The monthly average was calculated when we had 27 daily mean values; an annual value was calculated when we had 324 daily mean values. Besides this, manual inspection was carried out to remove abnormal values e.g., $\mathrm{PM}_{2.5}$ values higher than $\mathrm{PM}_{10}$ values.

\subsection{Kriging (Ordinary/Universal)}

Kriging is a geospatial interpolation technique that defines the unknown values depending on the available known values and considers both the distance and the degree of variation between known data points when estimating values in unknown areas. We used kriging (ordinary) to evaluate the spatial distribution of criteria pollutants $\left(\mathrm{PM}_{2.5}, \mathrm{PM}_{10}\right.$, $\left.\mathrm{SO}_{2}, \mathrm{NO}_{2}, \mathrm{CO}, \mathrm{O}_{3}\right), \mathrm{AQI}$, etc., in NWC, and then applied reclassification to obtain the desired map format.

\subsection{Statistical Analysis}

In this study, we used the Statistical Package for Social Sciences (SPSS) for Windows (IBM SPSS Statistics, Version 25) to evaluate Pearson's correlation coefficient for criteria pollutants on an annual and seasonal basis. Pearson's correlation is a correlation coefficient commonly used in linear regression and used to measure the strength of relationships between the six air pollutants. The effect of a certain variable was considered statistically significant for $\mathrm{P}$ (0.01 and 0.05 ) (two tailed). Annual mean values of data were used for the analysis of six criteria pollutants between 2019 to 2020: mean absolute deviation (MAD), mean square error (MSE), root mean square error (RMSE), mean absolute percentage error (MAPE), and mean percentage error (MPE), and were calculated by Excel 2016.

\section{Results}

\subsection{Annual and Seasonal Changes in Criteria Pollutants}

During the study period (2019-2020), the annual average concentration of $\mathrm{PM}_{2.5}$, $\mathrm{PM}_{10}, \mathrm{SO}_{2}, \mathrm{NO}_{2}, \mathrm{CO}$, and $\mathrm{O}_{3}$ (Table S1) improved by $2.72 \%, 5.31 \%, 7.93 \%, 8.40 \%, 8.47 \%$, and $2.15 \%$, respectively, in NWC (Figure 2). The annual average concentration of $\mathrm{PM}_{2.5}$ exceeded CAAQS Grade II standards ( $35 \mu \mathrm{g} / \mathrm{m}^{3}$, annual mean) in $\mathrm{SN}(24.91 \%), \mathrm{XJ}(38.94 \%)$, and NWC (6.1\%) (Figure 2a). Similarly, the annual average concentration of $\mathrm{PM}_{10}$ exceeded CAAQS Grade II standards (70 $\mathrm{gg} / \mathrm{m}^{3}$, annual mean) in SN $(8.71 \%), \mathrm{XJ}(72.13 \%), \mathrm{NX}$ $(12.45 \%)$, and NWC (18.74\%) (Figure $2 \mathrm{~b})$. While $\mathrm{SO}_{2}$ and $\mathrm{NO}_{2}$ complied with CAAQS Grade II standards ( $20 \mu \mathrm{g} / \mathrm{m}^{3}$ and $40 \mu \mathrm{g} / \mathrm{m}^{3}$, annual mean) in NWC (Figure 2c,d). CO and $\mathrm{O}_{3}$ do not have annual standards under CAAQS; both the $\mathrm{CO}$ and $\mathrm{O}_{3}$ decreased in $\mathrm{SN}, \mathrm{XJ}, \mathrm{GS}, \mathrm{NX}, \mathrm{QH}$, and NWC during 2020. The highest concentration of $\mathrm{PM}_{2.5}, \mathrm{PM}_{10}$, 
$\mathrm{SO}_{2}, \mathrm{NO}_{2}, \mathrm{CO}$, and $\mathrm{O}_{3}$ occurred in $\mathrm{XJ}, \mathrm{XJ}, \mathrm{NX}, \mathrm{SN}, \mathrm{XJ}$, and $\mathrm{QH}$, respectively. Figure 3 explains the spatial distribution of criteria pollutants in 53 cities of NWC during 2019 and 2020, obtained by kriging (ordinary) interpolation technique. The obtained results from spatial interpolation (kriging) were quite similar to the actual values. In 2020, $34(64.15 \%)$, $39(73.58 \%), 38(71.7 \%), 47(88.68 \%), 44(83.01 \%)$, and 38 (71.7\%) cities of NWC experienced a reduction in $\mathrm{PM}_{2.5}, \mathrm{PM}_{10}, \mathrm{SO}_{2}, \mathrm{NO}_{2}, \mathrm{CO}$, and $\mathrm{O}_{3}$, respectively (Figure 3).

$\mathrm{PM} 2.5, \mathrm{SO}_{2}, \mathrm{NO}_{2}$, and $\mathrm{CO}$ observed the highest value in winter and lowest in summer in a seasonal variation. The concentration of $\mathrm{PM}_{10}$ was highest in spring, while $\mathrm{O}_{3}$ was highest in summer and lowest in winter. The average concentration of $\mathrm{PM}_{2.5}, \mathrm{PM}_{10}, \mathrm{SO}_{2}$, $\mathrm{NO}_{2}$, and $\mathrm{CO}$ decreased in winter, spring, and summer 2020. In autumn 2020, $\mathrm{PM}_{2.5}, \mathrm{PM}_{10}$, $\mathrm{SO}_{2}$, and $\mathrm{NO}_{2}$ increased while $\mathrm{CO}$ decreased. $\mathrm{O}_{3}$ decreased in spring, summer, and autumn while it increased in winter 2020 as compared with 2019 (Figure 4). PM $_{2.5}$ exceeded the daily limits of CAAQS Grade II $\left(75 \mu \mathrm{g} / \mathrm{m}^{3}\right)$ during winter in SN $(2019)$, and XJ $(2019,2020)$ (Figure $4 \mathrm{a})$, while $\mathrm{PM}_{10}$ exceeded the daily limits of CAAQS Grade II $\left(150 \mathrm{\mu g} / \mathrm{m}^{3}\right)$ during spring in $\mathrm{XJ}(2019,2020)$ (Figure $4 \mathrm{~b})$. Gaseous pollutants $\left(\mathrm{SO}_{2}, \mathrm{NO}_{2}, \mathrm{CO}\right.$, and $\left.\mathrm{O}_{3}\right)$ complied with daily limits of CAAQS Grade II $\left(150 \mu \mathrm{g} / \mathrm{m}^{3}, 80 \mu \mathrm{g} / \mathrm{m}^{3}, 4 \mathrm{mg} / \mathrm{m}^{3}\right.$, and $\left.160 \mu \mathrm{g} / \mathrm{m}^{3}\right)$ in $\mathrm{SN}, \mathrm{XJ}, \mathrm{GS}, \mathrm{NX}, \mathrm{QH}$, and NWC (Figure 4c-f).

\section{2. $P M_{2.5} / P M_{10}$ Ratio}

During the study period (2019-2020), the average $\mathrm{PM}_{2.5} / \mathrm{PM}_{10}$ ratio in NWC ranged from $0.325 \pm 0.135$ to $0.640 \pm 0.190$ with an average of $0.472 \pm 0.100$, highest $\mathrm{PM}_{2.5} / \mathrm{PM}_{10}$ ratio occurring in $\mathrm{SN}$ followed by $\mathrm{QH}, \mathrm{NX}, \mathrm{GS}$, and $\mathrm{XJ}$, and experiencing an average change of $2.56 \%$ in NWC in 2020 as compared with 2019 (Figure 2h). In a seasonal variation, the highest $\mathrm{PM}_{2.5} / \mathrm{PM}_{10}$ ratio occurred in winter followed by autumn, summer, and spring, respectively, and increased by $10.68 \%$ in winter in NWC during 2020 (Figure 4h). In 2020, $62.26 \%$ of cities observed an increase in the $\mathrm{PM}_{2.5} / \mathrm{PM}_{10}$ ratio. Similarly, spring, summer, autumn and winter experienced an improvement in 33.96\%, 52.83\%, 54.72\%, and 90.57\% cities of NWC, respectively, in 2020 against 2019 (Figure 5).

\subsection{Air Quality Index (AQI)}

During the study period (2019-2020), the average AQI in NWC ranged from $43.34 \pm 10.15$ to $194 \pm 210.26$ with an average of $79.65 \pm 19.90$, and the highest AQI occurred in XJ followed by SN, GS, NX, and QH. The AQI improved by $4.67 \%(10.26 \%, 2.25 \%, 2.73 \%, 0.31 \%, 9.74 \%)$ in NWC (SN, XJ, GS, NX, QH) during 2020 as compared with 2019 (Figure 2g). In a seasonal variation, the highest AQI occurred in winter followed by spring, summer, and autumn, respectively, and improved by $6.69 \%, 2.91 \%, 8.57 \%$, and $1.59 \%$, respectively, in NWC during 2020 (Figure 4g). Seasonal variation was not consistent throughout NWC e.g., SN and XJ experienced the highest AQI in winter, GS and NX in spring. At the same time, $\mathrm{QH}$ observed the highest $\mathrm{AQI}$ in summer. Figure 6 illustrates the annual and seasonal spatial distribution of the AQI in NWC. In 2020, 77.36\% cities experienced an improvement in the AQI. Similarly, spring, summer, autumn and winter experienced an improvement of $83.02 \%, 13.21 \%, 52.83 \%$, and $62.26 \%$ in the cities of NWC, respectively, in 2020 against 2019. Significant improvement in the AQI occurred in winter (December to February) and spring (March to April) when the viral outbreak, lockdown, and movement restrictions were at their peak. 

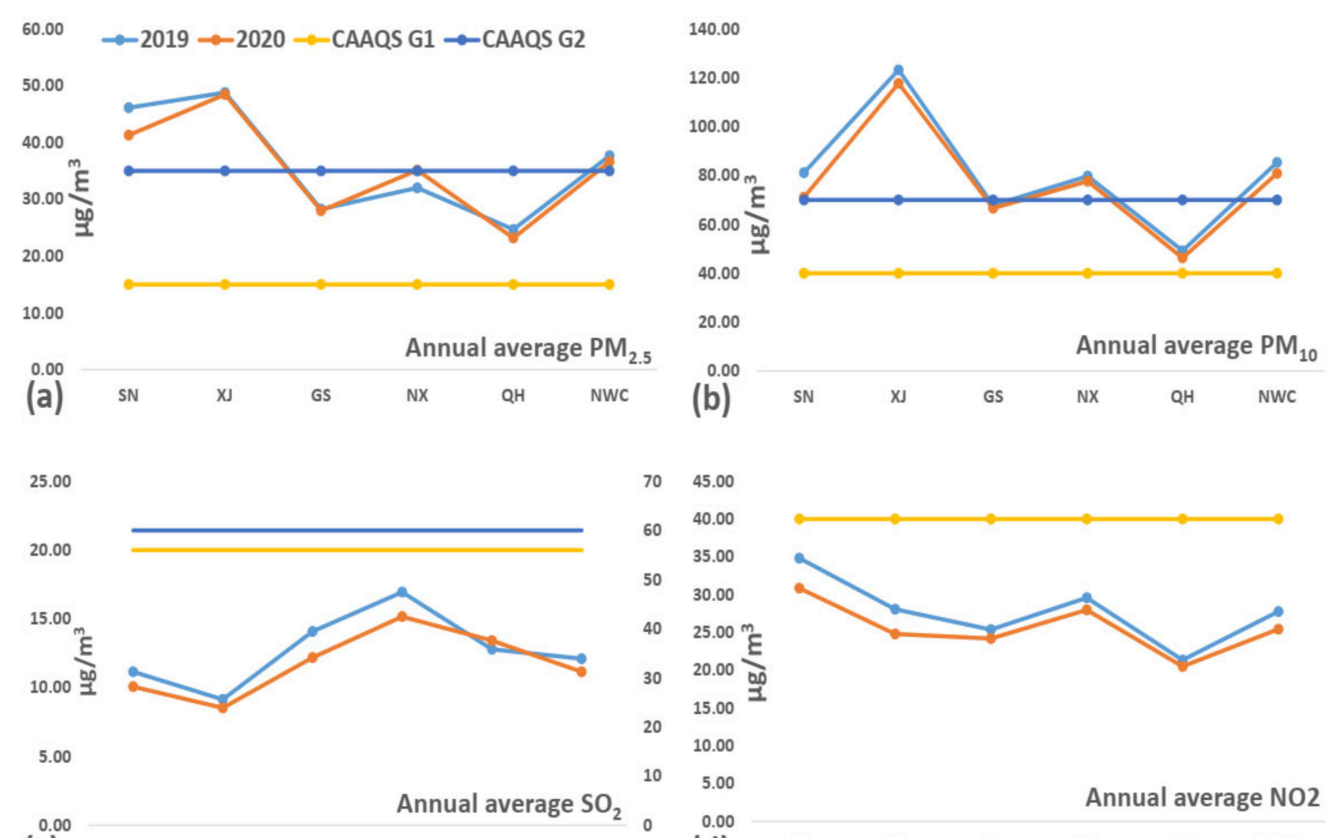

(b)
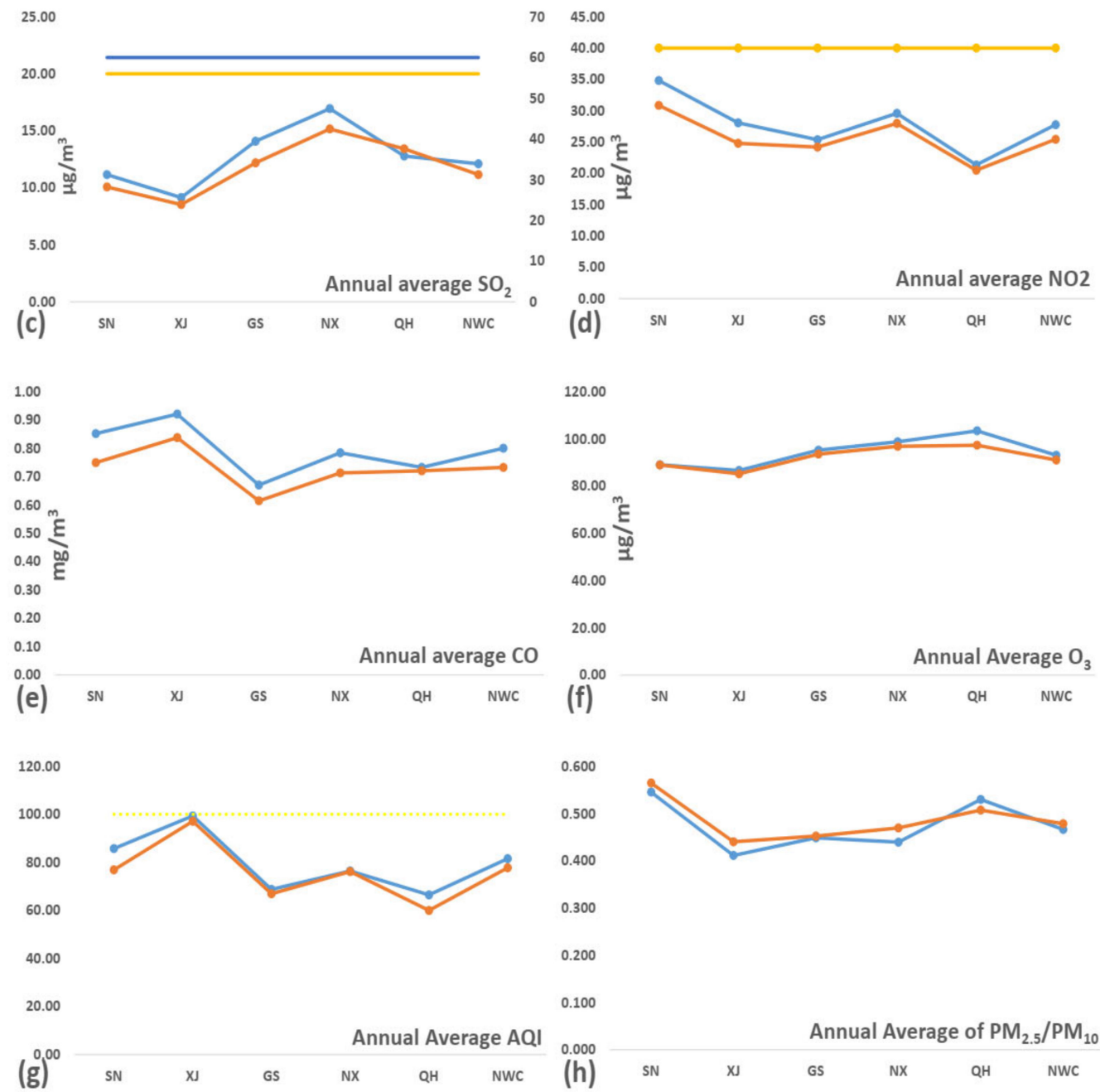

Figure 2. Influence of SARS-CoV-2 on the annual variation of six criteria pollutants: $\mathrm{PM}_{2.5}(\mathbf{a}), \mathrm{PM}_{10}(\mathbf{b}), \mathrm{SO}_{2}(\mathbf{c}), \mathrm{NO}_{2}$ (d), $\mathrm{CO}(\mathbf{e})$, and $\left.\mathrm{O}_{3}(\mathbf{f})\right)$, AQI (g), and PM2.5/PM 10 (h) in five provinces (Shaanxi (SN), Xinjiang (XJ), Gansu (GS), Ningxia (NX), and Qinghai (QH)) of northwest China (NWC) during 2019-2020. Descriptions are as follows: blue line (2019), orange line (2020), yellow line (CAAQS Grade I), blue line (CAAQS Grade II), and yellow dotted line (AQI threshold). The abbreviations are as follows: $\mathrm{PM}_{2.5}$ (fine particulate matter), $\mathrm{PM}_{10}$ (coarse particulate matter), $\mathrm{SO}_{2}$. (Sulfur dioxide), $\mathrm{NO}_{2}$ (nitrogen dioxide), $\mathrm{CO}$ (carbon monoxide), $\mathrm{O}_{3}$ (ozone), CAAAQS (Chinese Ambient Air Quality Standards). 


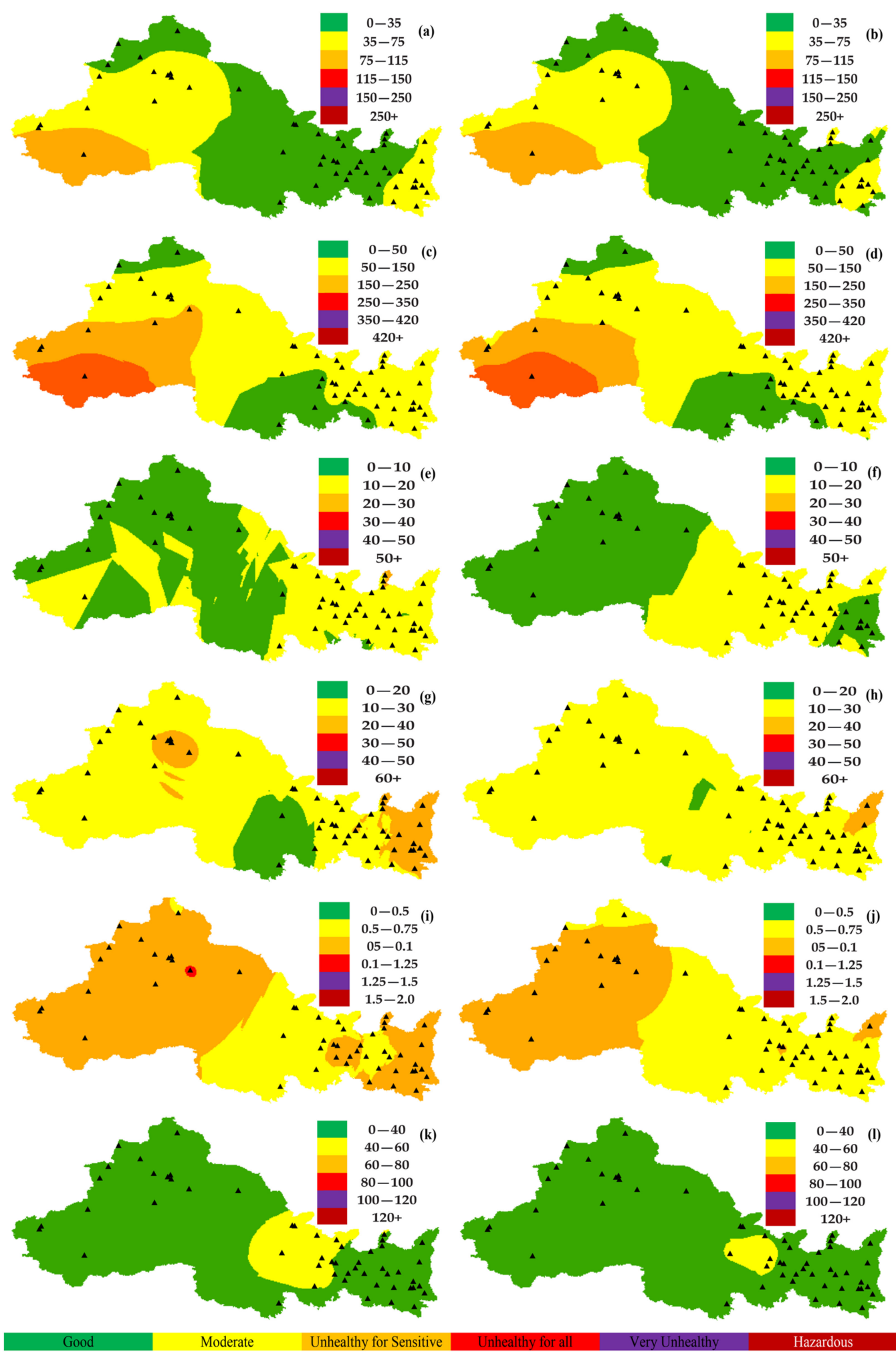

Figure 3. Spatial distribution of $\mathrm{PM}_{2.5}(\mathbf{a}, \mathbf{b}), \mathrm{PM}_{10}(\mathbf{c}, \mathbf{d}), \mathrm{SO}_{2}(\mathbf{e}, \mathbf{f}), \mathrm{NO}_{2}(\mathbf{g}, \mathbf{h}), \mathrm{CO}(\mathbf{i}, \mathbf{j})$, and $\mathrm{O}_{3}(\mathbf{k}, \mathbf{i})$ in northwest China (NWC) during 2019 and 2020. Colors represent the different pollution levels e.g., green (good), yellow (moderate), orange (unhealthy for the sensitive group), red (unhealthy for all), purple (very unhealthy), and maroon (hazardous). The abbreviations are as follows: $\mathrm{PM}_{2.5}$ (fine particulate matter), $\mathrm{PM}_{10}$ (coarse particulate matter), $\mathrm{SO}_{2}$. (Sulfur dioxide), $\mathrm{NO}_{2}$ (nitrogen dioxide), $\mathrm{CO}$ (carbon monoxide), and $\mathrm{O}_{3}$ (ozone). 

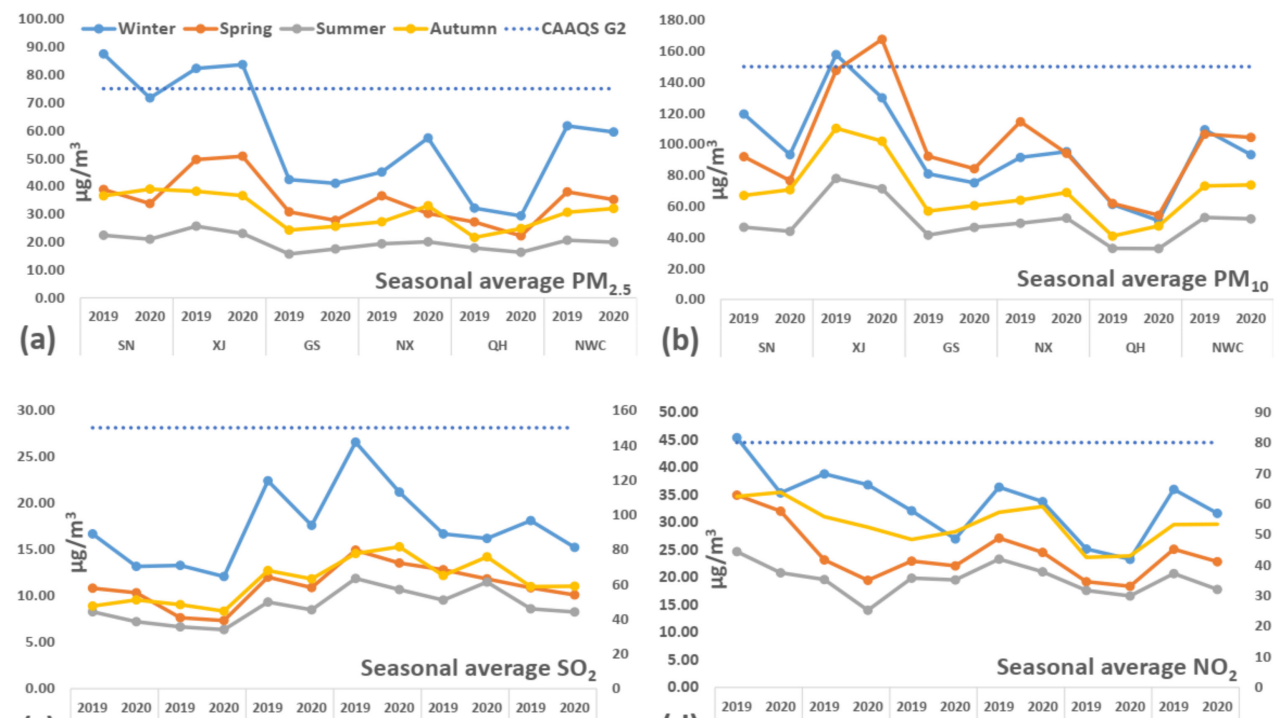

\begin{tabular}{lll|l|l|l|l} 
(c) & $\mathrm{SN}$ & $\mathrm{NJ}$ & $\mathrm{GS}$ & $\mathrm{NX}$ & ан & $\mathrm{NWC}$
\end{tabular}
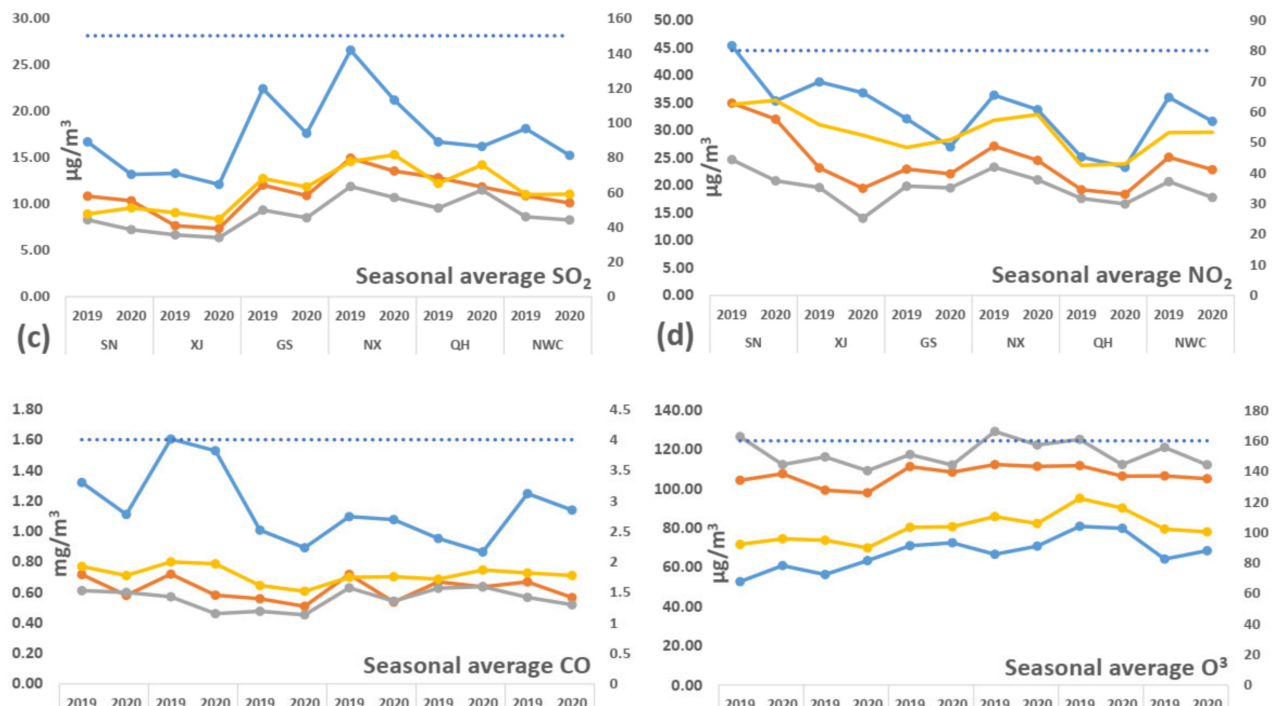

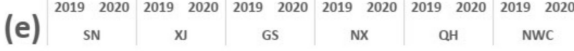
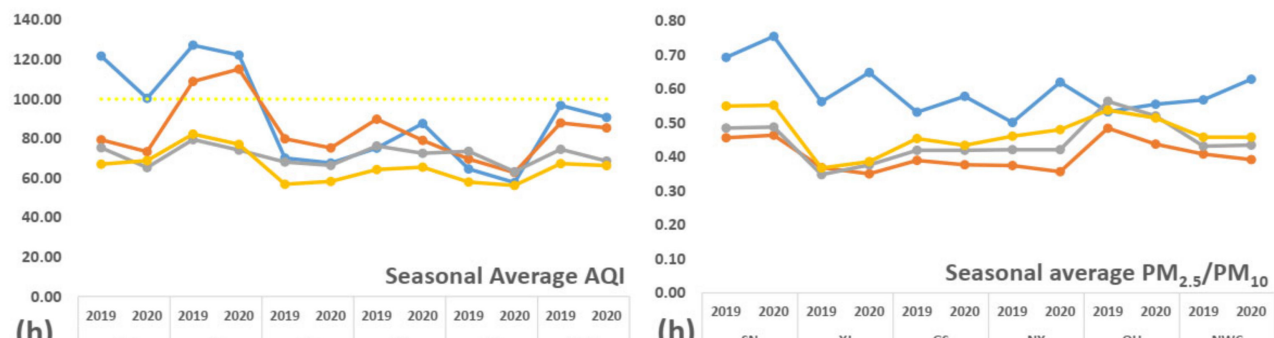

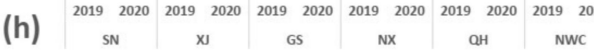

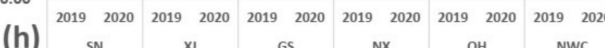

Figure 4. Influence of SARS-CoV-2 on seasonal variation of six pollutants: $\mathrm{PM}_{2.5}(\mathbf{a}), \mathrm{PM}_{10}(\mathbf{b}), \mathrm{SO}_{2}(\mathbf{c}), \mathrm{NO}_{2}(\mathbf{d}), \mathrm{CO}_{(\mathbf{e}), \mathrm{O}_{3}}$ (f); AQI (g), and $\mathrm{PM}_{2.5} / \mathrm{PM}_{10}$ ratio (h) in five provinces (Shaanxi (SN), Xinjiang (XJ), Gansu (GS), Ningxia (NX), and Qinghai $(\mathrm{QH})$ ) of northwest China (NWC) during 2019-2020. Descriptions are as follows: blue line (winter), orange line (spring), gray line (summer), yellow line (autumn), blue dotted line (CAAQS Grade II), and yellow dotted line (AQI threshold). The abbreviations are as follows: $\mathrm{PM}_{2.5}$ (fine particulate matter), $\mathrm{PM}_{10}$ (coarse particulate matter), $\mathrm{SO}_{2}$. (Sulfur dioxide), $\mathrm{NO}_{2}$ (nitrogen dioxide), $\mathrm{CO}$ (carbon monoxide), $\mathrm{O}_{3}$ (ozone), $\mathrm{PM}_{2.5} / \mathrm{PM}_{10}$ (ratio of $\mathrm{PM}_{2.5}$ with $\mathrm{PM}_{10}$ ), and $\mathrm{AQI}$ (air quality index). 


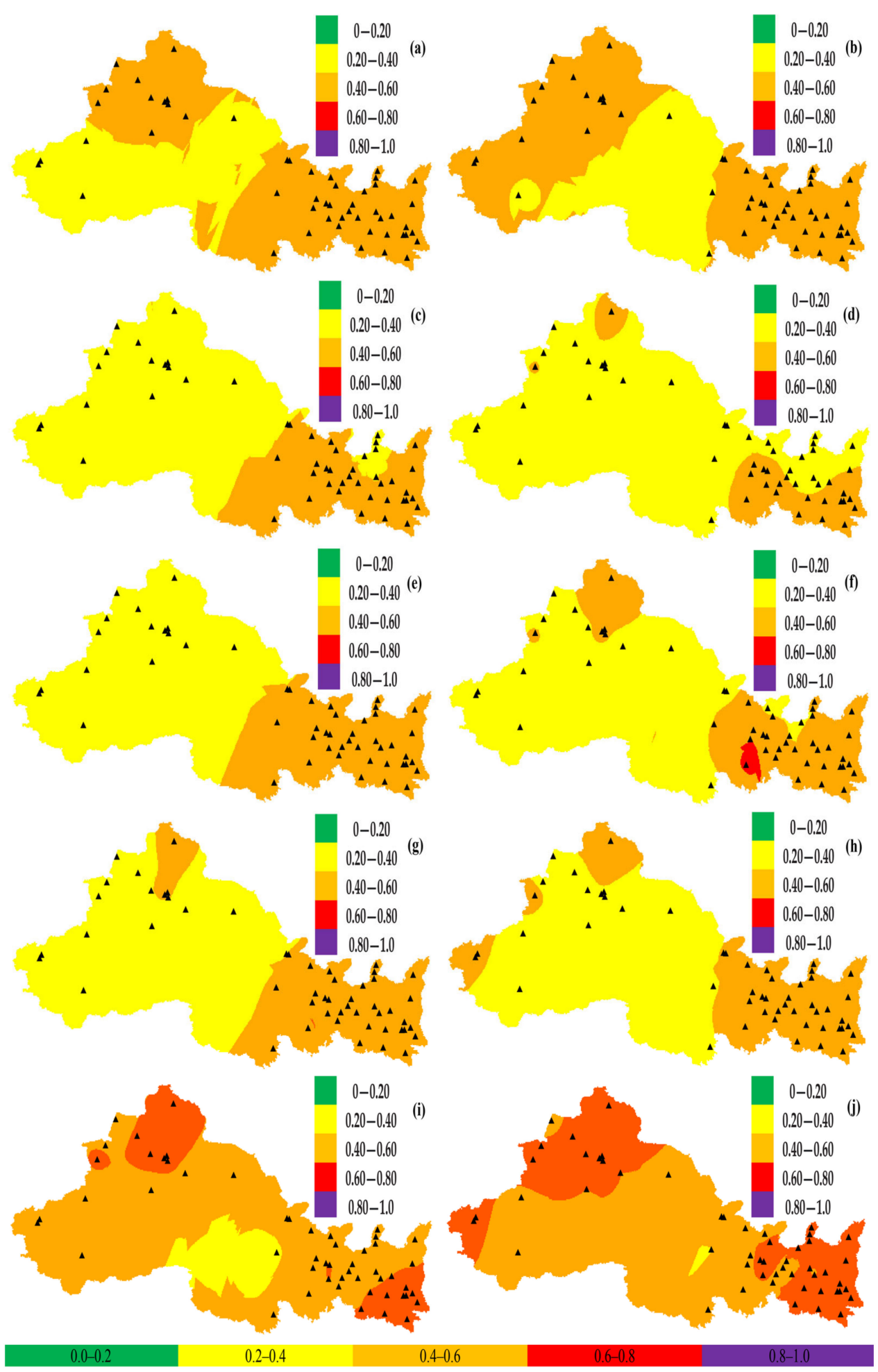

Figure 5. Annual $(\mathbf{a}, \mathbf{b})$ and seasonal (spring $(\mathbf{c}, \mathbf{d})$, summer $(\mathbf{e}, \mathbf{f})$, autumn $(\mathbf{g}, \mathbf{h})$, winter $(\mathbf{i}, \mathbf{j}))$ variation of $\mathrm{PM}_{2.5} / \mathrm{PM}_{10}$ ratio in northwest China (NWC) during 2019 and 2020. Colors represent the different pollution levels e.g., green (good), yellow (moderate), orange (unhealthy for the sensitive group), red (unhealthy for all), and purple (very unhealthy). 

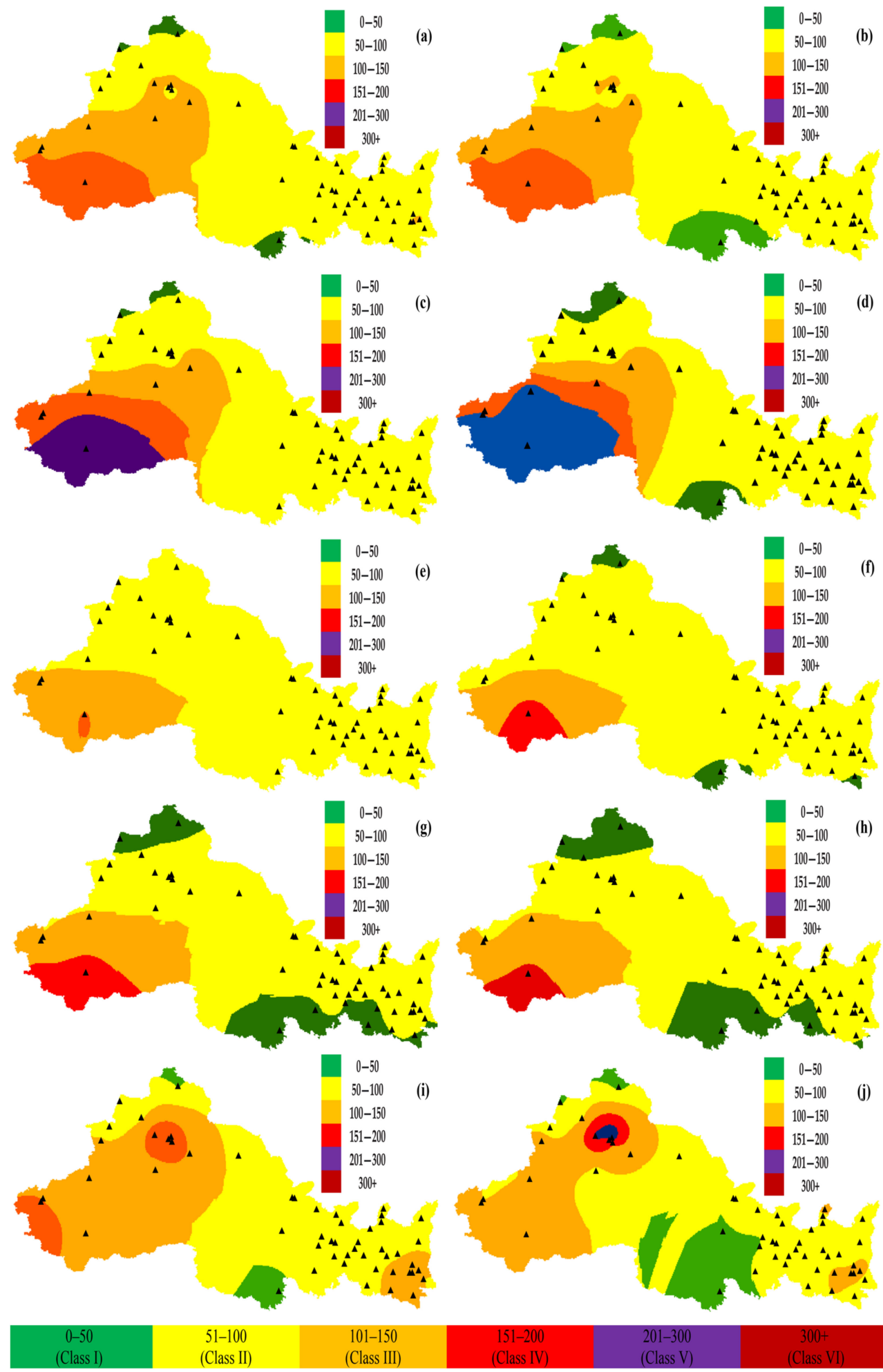

Figure 6. Annual $(\mathbf{a}, \mathbf{b})$ and seasonal (spring $(\mathbf{c}, \mathbf{d})$, summer $(\mathbf{e}, \mathbf{f})$, autumn $(\mathbf{g}, \mathbf{h})$, winter $(\mathbf{i}, \mathbf{j}))$ variation of AQI in northwest China (NWC) during 2019 and 2020. Colors represent the different classes of air quality index e.g., green (0-50, good, Class I), yellow (51-100, moderate, Class II), orange (101-150, unhealthy for the sensitive group, Class III), red (151-200, unhealthy for all, Class IV), purple (201-300, very unhealthy, Class V), and maroon (300+, hazardous, Class VI). 


\subsection{Proportion of Six AQI Classes}

Figure 7 explains the annual and seasonal (spring, summer, autumn, and winter) proportion of different AQI classes in NWC during 2019 and 2020. In 2020, the proportion of AQI "Class I", and "Class II" improved by $32.14 \%$, and $4 \%$, respectively, while they decreased by $9.13 \%, 21.35 \%$, and $18.41 \%$ for "Class III", "Class IV", and "Class V", respectively, in NWC. In the seasonal variation, the proportion of Class I increased by $22.42 \%$, $50.13 \%$, and $41.95 \%$ in spring, summer, and winter, respectively, in NWC during 2020. In the case of monthly variation, the combined proportion of Class I \& II was higher in summer (June, July, August), indicating better air quality compared with other seasons (Figure S1).

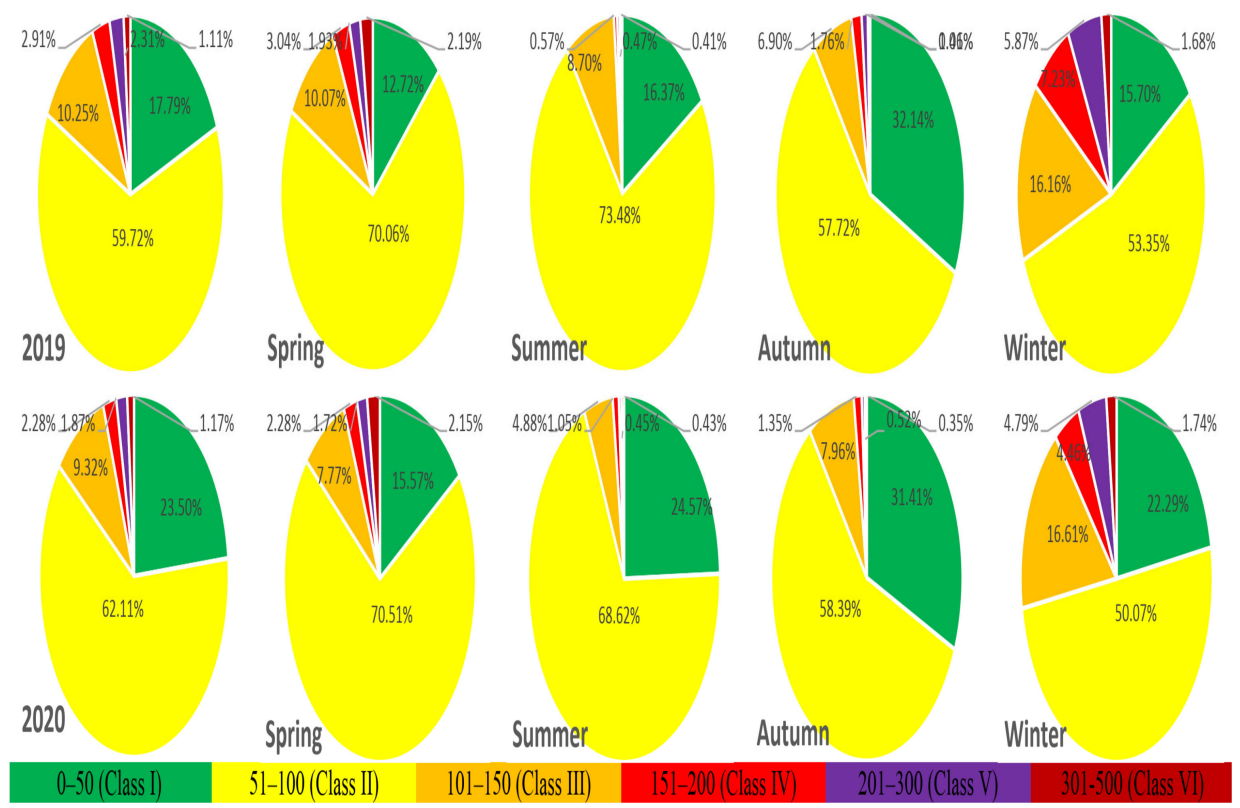

Figure 7. Annual and seasonal (spring, summer, autumn, winter) proportion of different air quality index (AQI) classes e.g., Class I (0—50, good, green), Class II (51-100, moderate, yellow), Class III (101-150, unhealthy for the sensitive group, orange), Class IV (151-200, unhealthy for all, red), Class V (201-300, very unhealthy, purple), and Class VI (300+, hazardous, maroon) in northwest China (NWC) during 2019 and 2020.

\subsection{The Major Pollutants}

During the study period, $\mathrm{O}_{3}$ was a major pollutant accounting for $28.06 \%$ days followed by $\mathrm{PM}_{2.5}(23.41 \%), \mathrm{PM}_{10}(21.79 \%), \mathrm{NO}_{2}(2.28 \%), \mathrm{SO}_{2}(0.21 \%)$, and $\mathrm{CO}(0.04 \%)$. In 2020, the number of days with $\mathrm{PM}_{2.5}, \mathrm{SO}_{2}$, and $\mathrm{NO}_{2}$ as major pollutants decreased by $46.02 \%, 51.79 \%$, and $34.77 \%$, respectively, while they increased by $119.45 \%, 300 \%$, and $3.10 \%$ for $\mathrm{PM}_{2.5}, \mathrm{CO}$, and $\mathrm{NO}_{2}$, respectively (Figure $\mathrm{S} 2$ ).

In the case of seasonal variation, $\mathrm{PM}_{10}$ was a major pollutant in spring $(43.57 \%)$ and autumn $(39.32 \%), \mathrm{PM}_{2.5}$ was a major pollutant in winter $(46.98 \%)$, and $\mathrm{O}_{3}$ was a major pollutant $(67.31 \%)$ in summer. The number of days with $\mathrm{PM}_{2.5}$ as a major pollutant decreased by $37.5 \%$ in spring, while they increased by $33.33 \%, 47.15 \%$, and $17.65 \%$ in summer, autumn, and winter 2020, respectively. Similarly, the number of days with $\mathrm{PM}_{10}$ as major pollutant increased by $0.61 \%, 21.33 \%$, and $8.75 \%$ in spring, summer, and autumn 2020, respectively, while they decreased by $32.31 \%$ in winter 2020 as compared with 2019 . The number of days with $\mathrm{SO}_{2}, \mathrm{NO}_{2}$ and $\mathrm{O}_{3}$ as major pollutant decreased in all seasons while increasing slightly for $\mathrm{O} 3$ in spring 2020 compared with 2019. The number of days with $\mathrm{O}_{3}$ as a major pollutant was higher in the hotter months (April-September), and $\mathrm{PM}_{2.5}$ was higher in colder months (November-February). $\mathrm{PM}_{10}$ experienced a " $\mathrm{U}$ " shaped curve 
with higher concentrations in winter, spring, and autumn, and lower concentrations in summer (Figure S2).

\subsection{Pollution Days}

Any day with one or more pollutants exceeding CAAQS (Grade II) standards is considered as a non-attainment/pollution day. Figure S3 explains the number of pollution days in NWC (SN, XJ, GS, NX, and QH) during 2019 and 2020. In 2020, the number of pollution days in NWC (SN, XJ, GS, NX, and QH) was reduced by $13.59 \%(22.33 \%, 13.96 \%$, $13.12 \%, 27.48 \%$, and $20.53 \%$ ) as compared with 2019 . Similarly, the number of pollution days decreased by $15.41 \%, 26.79 \%, 9.66 \%$, and $11.55 \%$ in spring, summer, autumn, and winter 2020, respectively, as compared with 2019 (Figure S3).

\subsection{Statistical Analysis}

$\mathrm{PM}_{2.5}$ was strongly correlated with $\mathrm{PM}_{10}, \mathrm{CO}, \mathrm{SO}_{2}$, and $\mathrm{NO}_{2}$, indicating emissions from fossil fuel combustion, power plants, vehicular exhaust, industrial emissions, dust storms etc. $\mathrm{O}_{3}$ was negatively correlated with other pollutants in northwest China. The seasonal variation in the correlation between different pollutants was evident. Throughout the study period, all the pollutants were positively correlated with each other except $\mathrm{O}_{3}$. A weak positive correlation occurred between $\mathrm{O}_{3}$ and other pollutants in summer (Table S2).

\section{Discussion}

Based on the results above, we concluded that the pollution level improved significantly in NWC during the COVID-19 outbreak (2020) due to strict epidemic prevention and control measures. In 2020, $\mathrm{PM}_{2.5}$ improved significantly in SN and QH, while it improved slightly in GS and XJ due to strict epidemic prevention measures e.g., industrial closure, traffic stagnation, etc. that significantly helped in pollution reduction $[27,29,30]$. Even after the epidemic prevention measures, NX experienced an increase in pollution, GS and XJ experienced minor improvements that indicate the influence of increased coal consumption, civil heating, industrial activity, etc. [6,13,19,27,44-48]. $\mathrm{PM}_{2.5}$ mainly originates from industrial activities, coal consumption, power generation, biomass burning, automobile exhausts, construction activities, road dust, etc. [7,8,10,19,45,49-51]. In 2020,64.15\% of cities in NWC experienced an improvement in $\mathrm{PM}_{2.5}$ with the highest number of cities in SN (90\%) followed by QH (87.5\%), GS (57.15\%), XJ (53.25\%), and NX (20\%), respectively, because the lockdown period was not consistent throughout NWC, and experienced significant spatial and temporal variation. With $\mathrm{PM}_{10}$, all regions e.g., $\mathrm{SN}, \mathrm{QH}, \mathrm{XJ}, \mathrm{NX}$, and GS experienced pollution reduction due to strict epidemic prevention measures $[27,29,30]$. $\mathrm{PM}_{10}$ mainly originates from natural sources e.g., sand storms, haze events, etc. as well as from anthropogenic sources e.g., developmental activities, industrial emissions, traffic emissions, road dust etc. [11,13,19] that were largely reduced during lockdowns, and helped significantly in pollution reduction $[27,30,35,38]$. XJ's southern region experienced the highest $\mathrm{PM}_{10}$ pollution level due to increased emissions from natural sources, e.g., Taklimakan deserts [52-55]. About 73.58\% of cities in NWC experienced a decrease in $\mathrm{PM}_{10}$ with the highest number of cities in QH (90\%), followed by XJ (75\%), GS (42.85\%), and NX (20\%) in 2020. Multiple studies experienced particulate reduction during the COVID-19 outbreak, e.g., [27] observed that $\mathrm{PM}_{2.5}$ and $\mathrm{PM}_{10}$ reduced by $30.1 \%$ and $40.5 \%$ in Hubei province [27], 46.5\% and 48.9\% in Anhui province [30], and 5.93\% and $13.66 \%$ in 44 cities of north China [31].

In the case of gaseous pollutants, $\mathrm{SO}_{2}, \mathrm{NO}_{2}, \mathrm{CO}$, and $\mathrm{O}_{3}$ decreased in all provinces and decreased in $71.7 \%, 88.68 \%, 83.02 \%$, and $71.7 \%$ in cities of NWC, respectively, during the COVID-19 year of 2020. Industrial emissions, coal burning, fossil fuel burning, power generation, traffic exhausts, etc., are major sources of $\mathrm{SO}_{2}, \mathrm{NO}_{2}$, and $\mathrm{CO}$ [45,56-60]. Due to epidemic prevention and control measures, industrial buildings were closed, energy demand was decreased, traffic was stagnant due to "stay at home", "self-quarantine", and 
"social distancing" policies that significantly reduced pollution in northwest China during 2020. Multiple studies e.g., [27] observed that $\mathrm{SO}_{2}$ decreased by $33.4 \%$ in Hubei, $52.5 \%$ in Anhui [30], 6.76\% in north China [31], 30\% in Wuhan (origin of the viral outbreak) [29], 20 to $30 \%$ reduction in China, Spain, France, Italy and northwestern parts of the USA. Similarly, $\mathrm{NO}_{2}$ and $\mathrm{CO}$ decreased by $61.4 \%$ and $27.9 \%$ in Hubei province [27], $52.8 \%, 36.2 \%$ in Anhui province [30], 24.67\%, and $4.58 \%$ in north China [31]. Similarly, [38] observed that $\mathrm{NO}_{2}$ and $\mathrm{CO}$ decreased by $30 \%$ in east China, and $20 \%$ in Wuhan, respectively, during the lockdown. $\mathrm{O}_{3}$ is a secondary pollutant formed due to a photochemical reaction between VOCs and NOx [27,30,61]. In contrast to other areas [4,27,30,37,62], the average concentration of $\mathrm{O}_{3}$ decreased by $2.15 \%$ in NWC, mainly because of a reduction in $\mathrm{O}_{3}$ precursors during lockdown period.

Generally, $\mathrm{PM}_{2.5}, \mathrm{PM}_{10}$ (except XJ in 2020, GS (2019, 2020), NX (2019), QH (2020)), $\mathrm{SO}_{2}$, $\mathrm{NO}_{2}$, and $\mathrm{CO}$ observed the same seasonal variation, e.g., highest in winter and lowest in summer. Higher pollution in winter is associated with increased coal combustion, civil heating, power generation, fossil fuel burning, industrial activity, vehicular exhausts, and stagnant meteorology $[13,44,46,51,63]$. The exception was that, the concentration of $\mathrm{PM}_{10}$ was higher in XJ during spring 2020 than in 2019, which indicates the ongoing influence of natural sources, e.g., sand storms, deserts, mineral dust, etc. [52-55]. In contrast to other pollutants, the concentration of $\mathrm{O}_{3}$ was higher in summer than winter $[13,46,51,64]$ due to lower NOx levels in winter, as NOx levels decrease the $\mathrm{O}_{3}$ depletion and enhance the accumulation of $\mathrm{O}_{3}$, as well as higher temperatures favor ozone production $[23,27,30,36,37$, 65-70]. Lockdown caused minor changes in seasonal variation instead of major changes because the lockdown pattern was not regular and largely varied spatially and temporally.

$\mathrm{PM}_{2.5} / \mathrm{PM}_{10}$ reflect air quality, pollution sources and origin e.g., a higher $\mathrm{PM}_{2.5} / \mathrm{PM}_{10}$ ratio indicates an increased proportion of $\mathrm{PM}_{2.5}$ mainly emitted from anthropogenic activities $[52,53,55]$. In 2020 , the $\mathrm{PM}_{2.5} / \mathrm{PM}_{10}$ ratio increased by $2.56 \%$, and $60.38 \%$ of cities experienced an increase in the $\mathrm{PM}_{2.5} / \mathrm{PM}_{10}$ ratio in NWC. This increase is associated with a minor reduction in $\mathrm{PM}_{2.5}$ as compared with $\mathrm{PM}_{10}$ in 2020. As the share of $\mathrm{PM}_{2.5}$ increases, the $\mathrm{PM}_{2.5} / \mathrm{PM}_{10}$ ratio also increases [13]. In general, the $\mathrm{PM}_{2.5} / \mathrm{PM}_{10}$ ratio was higher in winter (low temperature), compared to summer (high temperature) due to increased $\mathrm{PM}_{2.5}$ emissions from coal combustion, civil heating, biomass burning, industrial emissions, and stable atmospheric conditions helped with stagnation and accumulation of pollution [13,71-73]. In 2020, the $\mathrm{PM}_{2.5} / \mathrm{PM}_{10}$ ratio decreased in spring and summer, while it increased in autumn and winter due to an increase in $\mathrm{PM}_{2.5}$ and minor reduction of $\mathrm{PM}_{2.5}$ compared with $\mathrm{PM}_{10}$.

In 2020 , the AQI improved by $4.70 \%(10.26 \%, 2.25 \%, 2.73 \%, 0.31 \%$, and $9.74 \%)$ in NWC (SN, XJ, GS, NX, and QH), and 77.36\% (41/53) of cities in NWC experienced AQI improvement. This improvement is associated with a reduction in criteria pollutants during lockdown [27-39]. The AQI improvement throughout NWC was not uniform because of irregular lockdown periods, air quality deteriorated in some areas, and improved in some areas. In general, smaller cities ( $<1$ million) experienced greater improvement with some exceptions e.g., Shizuishan ( 0.73 million) and Linxia ( 0.25 million) experienced deterioration by $3.23 \%$ and $12.79 \%$, respectively. Similarly, some big cities ( $>5$ million), e.g., Xian, Weinan, Xianyang, experienced AQI improvement of more than $12 \%$. In seasonal variations, the highest AQI occurred in winter because the concentration of criteria pollutants was higher in winter due to increased anthropogenic emissions in winter and stable atmospheric conditions [11,19,71-74]. In 2020, the AQI improved in all seasons, e.g., spring $(83.02 \%)$, summer $(13.21 \%)$, autumn (52.83\%), and winter (62.26\%) compared with 2019. In NWC, the combined proportion of AQI "Class I", and "Class II" improved by $10.46 \%$ in 2020 compared with 2019, which indicates improvement in air quality [13,71]. In 2020, the highest combined proportion of AQI "Class I", and "Class II" occurred in summer followed by autumn, spring and winter, increased in all seasons except autumn as compared with 2019. The combined proportion of AQI "Class I" and "Class II" improved in all provinces except in winter for NX and autumn for SN, GS, NX, and QH in 2020 compared with 2019. Similar studies, e.g., [27] observed that Class I, and Class II increased significantly, while 
the proportion of Class III, Class IV, Class V, and Class VI decreased in Hubei and Anhui province during lockdown [30].

In 2020, the number of days with $\mathrm{PM}_{10}$ and $\mathrm{O}_{3}$ as major pollutants increased, while the number of days with $\mathrm{PM}_{2.5}, \mathrm{SO}_{2}$, and $\mathrm{NO}_{2}$ as major pollutants decreased in NWC concerning 2019. Due to limited anthropogenic activity e.g., industrial closures, traffic stagnation, movement restrictions etc., the concentration of $\mathrm{PM}_{2.5}, \mathrm{SO}_{2}$, and $\mathrm{NO}_{2}$ decreased significantly $[23,27,30,31,36,38]$. $\mathrm{PM}_{2.5}$ was a major pollutant in winter, indicating anthropogenic emissions, e.g., civil heating, industrial emissions, etc. [13,47,48,71]. $\mathrm{PM}_{10}$ was a major pollutant in spring and autumn, while $\mathrm{O}_{3}$ was a major pollutant in summer as higher temperatures favor ozone accumulation [35,64-69]. In the southern part of XJ (Kashgar), the number of days with $\mathrm{PM}_{10}$ as a major pollutant was higher due to emissions from natural sources, e.g., Taklimakan desert, sand storms [52-55,75]. Any day with one or more pollutants exceeding CAAQS (Grade II) standards is considered as a non-attainment/pollution day [27,30]. During 2020, the number of pollution days decreased by $13.59 \%$ in NWC, which indicates improved air quality associated with a reduction in anthropogenic activities. Similarly, the number of pollution days decreased by $15.41 \%, 26.79 \%, 9.66 \%$, and $11.55 \%$ in spring, summer, autumn, and winter, respectively, which indicates that the ambient air quality was improved significantly in 2020. A strong correlation between all the criteria pollutants indicates mutual emission sources. $\mathrm{PM}_{2.5}$, mainly originates from anthropogenic activity e.g., fossil fuels, developmental activity, industrial activity, etc. $[7,8,11,15]$. Such activities also contribute to $\mathrm{SO}, \mathrm{NO}_{2}, \mathrm{CO}$ and $\mathrm{PM}_{10}$. Multiple studies have concluded that coal burning is a major source of $\mathrm{PM}_{2.5}[8,76]$ and a major source of $\mathrm{SO}_{2}$; vehicular emissions are a major source of $\mathrm{PM}_{2.5}[49,77,78]$ and release $\mathrm{NO}_{2}$ and $\mathrm{CO}$ as well. Similarly, road dust mainly consists of $\mathrm{PM}_{10}$, which contributes a significant share to $\mathrm{PM}_{2.5}[10,18,49,77,79]$.

In short, ongoing rapid economic development, industrialization, urbanization, motorization, natural events, and adverse meteorology have deteriorated ambient air quality in NWC $[2,9,16,18,80-83]$. The SARS-CoV-2 proved to be a blessing in disguise as the associated lockdowns put in place to prevent the spread of the viral outbreak resulted in a significant reduction in $\mathrm{PM}_{2.5}, \mathrm{PM}_{10}, \mathrm{SO}_{2}, \mathrm{NO}_{2}, \mathrm{CO}, \mathrm{O}_{3}, \mathrm{AQI}$, and the number of pollution days in NWC decreased during 2020 compared to 2019.

\section{Conclusions}

This study collected hourly monitoring data of ambient air pollutants from 53 cities located in five provinces of northwest China (NWC) from January 2019 to December 2020 to show the collective effect SARS-CoV-2 had on ambient air quality in 2020 as compared with 2019. The results showed that the average concentrations of $\mathrm{PM}_{2.5}, \mathrm{PM}_{10}$, $\mathrm{SO}_{2}, \mathrm{NO}_{2}, \mathrm{CO}$, and $\mathrm{O}_{3}$ improved by $2.72 \%, 5.31 \%, 7.93 \%, 8.40 \%, 8.47 \%$, and $2.15 \%$ in $\mathrm{NWC}$, respectively, during 2020. The annual average concentration of $\mathrm{PM}_{2.5}$ failed to comply in $\mathrm{SN}, \mathrm{XJ}$, and $\mathrm{NW} ; \mathrm{PM}_{10}$ failed to comply in $\mathrm{SN}, \mathrm{XJ}, \mathrm{NX}$, and $\mathrm{NW}$, while $\mathrm{SO}_{2}$ and $\mathrm{NO}_{2}$ complied with CAAQS Grade II standards $\left(35 \mu \mathrm{g} / \mathrm{m}^{3}, 70 \mu \mathrm{g} / \mathrm{m}^{3}, 60 \mu \mathrm{g} / \mathrm{m}^{3}\right.$ and $40 \mu \mathrm{g} / \mathrm{m}^{3}$, annual mean) in SN, XJ, GS, NX, QH, and NWC. All the pollutants experienced their highest pollution level in winter except ozone, with varying degrees of spatial distribution. The AQI improved by $4.67 \%$ (higher in cities with low population, with some exceptions) in NWC and experienced the highest improvement in SN followed by QH, GS, XJ, and NX. The AQI improved in all seasons with the highest increase in summer, followed by winter, spring and autumn. Significant improvements in the AQI occurred in winter (December to February) and spring (March to April) when lockdowns, industrial closures etc. were at their peak. In NWC, $\mathrm{O}_{3}$ was a major pollutant followed by $\mathrm{PM}_{2.5}, \mathrm{PM}_{10}, \mathrm{NO}_{2}, \mathrm{SO}_{2}$, and, $\mathrm{CO}$ with different spatial and temporal variations, e.g., $\mathrm{PM}_{2.5}$ in winter, $\mathrm{PM}_{10}$ in autumn and spring, and $\mathrm{O}_{3}$ in summer. A strong correlation occurred between all pollutants except $\mathrm{O}_{3}$. This paper comprehensively discussed the impact of SARS-CoV-2, and associated lockdowns on air pollution in NWC and calls for future detailed assessment focusing on health risk assessment and the impact of meteorology, etc. 
Supplementary Materials: The following are available online at https: / www.mdpi.com/article/ 10.3390/atmos12040518/s1, Figure S1: Monthly variation in proportion of the air quality index (AQI) classes e.g., Class I (0-50, good, green), Class II (51-100, moderate, yellow), Class III (101-150, unhealthy for sensitive group, orange), Class IV (151-200, unhealthy for all, red), Class V (201300 , very unhealthy, purple), and Class VI (300+, hazardous, maroon) in northwest China (NWC) during 2019 and 2020; Figure S2: Annual, seasonal (a) and monthly (b) proportion of various major pollutants in northwest China (NWC) during 2019 and 2020. Descriptions are as follows: green (PM2.5), yellow (PM10), gray (SO2), orange (NO2), blue (CO), and light green (O3). The abbreviations are as follows: PM2.5 (fine particulate matter), PM10 (coarse particulate matter), SO2. (Sulfur dioxide), NO2 (nitrogen dioxide), CO (carbon monoxide), and O3 (ozone); Figure S3: Annual and seasonal proportion of pollution days in northwest China (NWC) during 2019 and 2020. Descriptions are as follows: blue bar (spring), orange bar (summer), gray bar (autumn), yellow bar (winter), and blue line (annual mean). Table S1: Annual average concentration of Pm2.5, PM10, SO2, NO2, CO, O3, and PM2.5/PM10 in northwest China (NWC) during 2019 and 2020. Table S2: Annual and seasonal correlation between different pollutants in 2019 and 2020.

Author Contributions: Conceptualization, S.Z.; data curation, S.Z.; investigation and data validation, J.L., M.Z.S. and I.S.; methodology, S.Z.; software, S.Z.; writing-original draft preparation, S.Z.; review and editing, J.L., M.Z.S., S.A., S.Z., I.S; supervision, J.L.; funding acquisition, J.L. All authors have read and agreed to the published version of the manuscript.

Funding: The National Natural Science Foundation of China (No. 21667026) and the Social Science Foundation of Xinjiang Production and Construction Corps (No. 18YB13) funded this work.

Institutional Review Board Statement: Not applicable.

Informed Consent Statement: Not applicable.

Data Availability Statement: The data presented in this study are available upon request from the corresponding author.

Acknowledgments: I would like to acknowledge Jianjiang Lu, research scholar Anam Arshad, and Babar Amin from Shihezi University, China for helping and guiding throughout the preparation of this paper.

Conflicts of Interest: The authors declare no conflict of interest.

\section{References}

1. Zhao, S.; Yin, D.; Yu, Y.; Kang, S.; Qin, D.; Dong, L. PM2.5 and O3 pollution during 2015-2019 over 367 Chinese cities: Spatiotemporal variations, meteorological and topographical impacts. Environ. Pollut. 2020, 264, 114694. [CrossRef]

2. Yang, J.; Ji, Z.; Kang, S.; Zhang, Q.; Chen, X.; Lee, S.Y. Spatiotemporal variations of air pollutants in western China and their relationship to meteorological factors and emission sources. Environ. Pollut. 2019, 254, 112952. [CrossRef]

3. Maji, K.J. Substantial changes in PM2.5 pollution and corresponding premature deaths across China during 2015-2019: A model prospective. Sci. Total Environ. 2020, 729, 138838. [CrossRef] [PubMed]

4. Li, R.; Wang, Z.; Cui, L.; Fu, H.; Zhang, L.; Kong, L.; Chen, J. Air pollution characteristics in China during 2015-2016: Spatiotemporal variations and key meteorological factors. Sci. Total Environ. 2019, 648, 902-915. [CrossRef] [PubMed]

5. Chen, J.; Lu, J.; Ning, J.; Yan, Y.; Li, S.; Zhou, L. Characteristics and sources analysis of PM 2.5 in a major industrial city of northern Xinjiang, China. SN Appl. Sci. 2020, 2, 1-9. [CrossRef]

6. Da Limu, Y.L.M.; LiFu, D.L.N.T.; Miti, A.B.; Wang, X.; Ding, X. Autumn and wintertime polycyclic aromatic hydrocarbons in $\mathrm{PM}_{2.5}$ and $\mathrm{PM}_{2.5-10}$ from Urumqi, China. Aerosol Air Qual. Res. 2013, 13, 407-414.

7. Feng, J.; Yu, H.; Mi, K.; Su, X.; Li, Y.; Li, Q.; Sun, J. One-year study of $\mathrm{PM}_{2.5}$ in Xinxiang city, North China: Seasonal characteristics, climate impact and source. Ecotoxicol. Environ. Saf. 2018, 154, 75-83. [CrossRef]

8. Ma, X.; Xiao, Z.; He, L.; Shi, Z.; Cao, Y.; Tian, Z.; Liu, J. Chemical Composition and Source Apportionment of PM 2.5 in Urban Areas of Xiangtan, Central South China. Int. J. Environ. Res. Public Health 2019, 16, 539. [CrossRef]

9. Shao, Z.; Jia, X.; Zhong, X.; Wang, D.; Wei, J.; Wang, Y.; Chen, L. Detection, extinguishing, and monitoring of a coal fire in Xinjiang, China. Environ. Sci. Pollut. Res. 2018, 25, 26603-26616. [CrossRef] [PubMed]

10. Tao, J.; Gao, J.; Zhang, L.; Zhang, R.; Che, H.; Zhang, Z.; Hsu, S.C. PM 2.5 pollution in a megacity of southwest China: Source apportionment and implication. Atmos. Chem. Phys. 2014, 14, 8679-8699. [CrossRef]

11. Turap, Y.; Rekefu, S.; Wang, G.; Talifu, D.; Gao, B.; Aierken, T.; Nuerla, A. Chemical Characteristics and Source Apportionment of $\mathrm{PM}_{2.5}$ during winter in the Southern Part of Urumqi, China. Aerosol Air Qual. Res. 2019, 19, 1325-1337. [CrossRef]

12. Thach, T.Q.; Tsang, H.; Cao, P.; Ho, L.M. A novel method to construct an air quality index based on air pollution profiles. Int. J. Hyg. Environ. Health 2018, 221, 17-26. [CrossRef] [PubMed] 
13. Yin, Z.; Cui, K.; Chen, S.; Zhao, Y.; Chao, H.R.; Chang-Chien, G.P. Characterization of the air quality index for Urumqi and Turfan cities, China. Aerosol Air Qual. Res. 2019, 19, 282-306. [CrossRef]

14. Fan, H.; Zhao, C.; Yang, Y. A comprehensive analysis of the spatio-temporal variation of urban air pollution in China during 2014-2018. Atmos. Environ. 2020, 220, 117066. [CrossRef]

15. Liu, B.; Wu, J.; Zhang, J.; Wang, L.; Yang, J.; Liang, D.; Zhang, Q. Characterization and source apportionment of PM 2.5 based on error estimation from EPA PMF 5.0 model at a medium city in China. Environ. Pollut. 2017, 222, 10-22. [CrossRef] [PubMed]

16. Luo, H.; Guan, Q.; Lin, J.; Wang, Q.; Yang, L.; Tan, Z.; Wang, N. Air pollution characteristics and human health risks in key cities of northwest China. J. Environ. Manage. 2020, 269, 110791. [CrossRef]

17. Landrigan, P.J.; Fuller, R.; Acosta, N.J.; Adeyi, O.; Arnold, R.; Baldé, A.B.; Chiles, T. The Lancet Commission on pollution and health. Lancet 2018, 391, 462-512. [CrossRef]

18. Qiu, Y.; Yang, T.; Seyler, B.C.; Wang, X.; Wang, Y.; Jiang, M.; Li, F. Ambient air pollution and male fecundity: A retrospective analysis of longitudinal data from a Chinese human sperm bank (2013-2018). Environ. Res. 2020, 186, 109528. [CrossRef]

19. Turap, Y.; Talifu, D.; Wang, X.; Abulizi, A.; Maihemuti, M.; Tursun, Y.; Rekefu, S. Temporal distribution and source apportionment of $\mathrm{PM}_{2.5}$ chemical composition in Xinjiang, NW-China. Atmos. Res. 2019, 218, 257-268. [CrossRef]

20. Cohen, A.J.; Brauer, M.; Burnett, R.; Anderson, H.R.; Frostad, J.; Estep, K.; Feigin, V. Estimates and 25-year trends of the global burden of disease attributable to ambient air pollution: An analysis of data from the Global Burden of Diseases Study 2015. Lancet 2017, 389, 1907-1918. [CrossRef]

21. Zhu, G.; Hu, W.; Liu, Y.; Cao, J.; Ma, Z.; Deng, Y.; Wang, H. Health burdens of ambient $\mathrm{PM}_{2.5}$ pollution across Chinese cities during 2006-2015. J. Environ. Manag. 2019, 24, 250-256. [CrossRef]

22. Wang, Q.; Wang, J.; Zhou, J.; Ban, J.; Li, T. Estimation of $\mathrm{PM}_{2.5}$ associated disease burden in China in 2020 and 2030 using population and air quality scenarios: A modelling study. Lancet Planet Health 2019, 3, 71-80. [CrossRef]

23. Mahato, S.; Pal, S.; Ghosh, K.G. Effect of lockdown amid COVID-19 pandemic on air quality of the megacity Delhi, India. Sci. Total Environ. 2020, 730, 139086. [CrossRef] [PubMed]

24. Hadei, M.; Hopke, P.K.; Jonidi, A.; Shahsavani, A. A letter about the airborne transmission of SARS-CoV-2 based on the current evidence. Aerosol Air Qual. Res. 2020, 20, 911-914. [CrossRef]

25. Zhu, N.; Zhang, D.; Wang, W.; Li, X.; Yang, B.; Song, J.; Niu, P. A novel coronavirus from patients with pneumonia in China, 2019. N. Engl. J. Med. 2020, 382, 727-733. [CrossRef] [PubMed]

26. Wu, Y.C.; Chen, C.S.; Chan, Y.J. The outbreak of COVID-19: An overview. J. Chin. Med. Assoc. 2020, 83, 217. [CrossRef]

27. Xu, K.; Cui, K.; Young, L.H.; Hsieh, Y.K.; Wang, Y.F.; Zhang, J.; Wan, S. Impact of the COVID-19 Event on Air Quality in Central China. Aerosol Air Qual. Res. 2020, 20, 915-929. [CrossRef]

28. Wang, X.; Zhang, R. How Did Air Pollution Change during the COVID-19 Outbreak in China? Bull. Am. Meteorol. Soc. 2020, 101, E1645-E1652. [CrossRef]

29. Muhammad, S.; Long, X.; Salman, M. COVID-19 pandemic and environmental pollution: A blessing in disguise? Sci Total Environ. 2020, 728, 138820. [CrossRef]

30. Xu, K.; Cui, K.; Young, L.H.; Wang, Y.F.; Hsieh, Y.K.; Wan, S.; Zhang, J. Air Quality Index, Indicatory Air Pollutants and Impact of COVID-19 Event on the Air Quality near Central China. Aerosol Air Qual. Res. 2020, 20, 1204-1221. [CrossRef]

31. Bao, R.; Zhang, A. Does lockdown reduce air pollution? Evidence from 44 cities in northern China. Sci. Total Environ. 2020, 731, 139052. [CrossRef] [PubMed]

32. Kumar, P.; Hama, S.; Omidvarborna, H.; Sharma, A.; Sahani, J.; Abhijith, K.V.; Tiwari, A. Temporary reduction in fine particulate matter due to 'anthropogenic emissions switch-off' during COVID-19 lockdown in Indian cities. Sustain. Cities Soc. 2020, 62, 102382. [CrossRef] [PubMed]

33. Otmani, A.; Benchrif, A.; Tahri, M.; Bounakhla, M.; El Bouch, M.; Krombi, M.H. Impact of Covid-19 lockdown on $\mathrm{PM}_{10}, \mathrm{SO}_{2}$ and $\mathrm{NO}_{2}$ concentrations in Salé City (Morocco). Sci. Total Environ. 2020, 735, 139541. [CrossRef] [PubMed]

34. Silver, B.; He, X.; Arnold, S.R.; Spracklen, D.V. The impact of COVID-19 control measures on air quality in China. Environ. Res. Lett. 2020, 15, 084021. [CrossRef]

35. Filonchyk, M.; Hurynovich, V.; Yan, H.; Gusev, A.; Shpilevskaya, N. Impact Assessment of COVID-19 on Variations of $\mathrm{SO}_{2}$, $\mathrm{NO}_{2}$, CO and AOD over East China. Aerosol Air Qual. Res. 2020, 20, 1530-1540. [CrossRef]

36. He, G.; Pan, Y.; Tanaka, T. The short-term impacts of COVID-19 lockdown on urban air pollution in China. Nat. Sustain. 2020, 3, 1005-1011. [CrossRef]

37. Lian, X.; Huang, J.; Huang, R.; Liu, C.; Wang, L.; Zhang, T. Impact of city lockdown on the air quality of COVID-19-hit of Wuhan city. Sci Total Environ. 2020, 742, 140556. [CrossRef]

38. Filonchyk, M.; Peterson, M. Air quality changes in Shanghai, China, and the surrounding urban agglomeration during the COVID-19 lockdown. J. Geovis Spat Anal. 2020, 4, 1-7. [CrossRef]

39. Xu, J.; Ge, X.; Zhang, X.; Zhao, W.; Zhang, R.; Zhang, Y. COVID-19 impact on the concentration and composition of submicron particulate matter in a typical city of Northwest China. Geophys. Res. Lett. 2020, 47, e2020GL089035. [CrossRef]

40. Wang, W.; Cui, K.; Zhao, R.; Hsieh, L.T.; Lee, W.J. Characterization of the air quality index for Wuhu and Bengbu cities, China. Aerosol Air Qual. Res. 2018, 18, 1198-1220. [CrossRef]

41. Cheng, W.L.; Chen, Y.S.; Zhang, J.; Lyons, T.J.; Pai, J.L.; Chang, S.H. Comparison of the revised air quality index with the PSI and AQI indices. Sci. Total Environ. 2007, 382, 191-198. [CrossRef] 
42. She, Q.N.; Peng, X.; Xu, Q.; Long, L.B.; Wei, N.; Liu, M.; Jia, W.X. Air quality and its response to satellite-derived urban form in the Yangtze River Delta, China. Int. J. Environ. Res. Public Health 2017, 75, 297-306. [CrossRef]

43. Shen, F.; Zhang, L.; Jiang, L.; Tang, M.; Gai, X.; Chen, M.; Ge, X. Temporal variations of six ambient criteria air pollutants from 2015 to 2018, their spatial distributions, health risks and relationships with socioeconomic factors during 2018 in China. Environ. Int. 2020, 137, 105556. [CrossRef]

44. Chen, J.; Lu, J.; Ning, J.; Yan, Y.; Li, S.; Zhou, L. Pollution characteristics, sources, and risk assessment of heavy metals and per fluorinated compounds in PM2.5 in the major industrial city of northern Xinjiang, China. Air Qual. Atmos. Health 2019, 12, 909-918. [CrossRef]

45. Ding, Y.; Lu, J.; Liu, Z.; Li, W.; Chen, J. Volatile organic compounds in Shihezi, China, during the heating season: Pollution characteristics, source apportionment, and health risk assessment. Environ. Sci. Pollut. Res. 2020, 27, 16439-16450. [CrossRef]

46. Wang, Y.; Ying, Q.; Hu, J.; Zhang, H. Spatial and temporal variations of six criteria air pollutants in 31 provincial capital cities in China during 2013-2014. Environ. Int. 2014, 73, 413-422. [CrossRef]

47. Zhang, Q.; Streets, D.G.; Carmichael, G.R.; He, K.B.; Huo, H.; Kannari, A.; Chen, D. Asian emissions in 2006 for the NASA INTEX-B mission. Atmos. Chem. Phys. 2009, 9, 5131-5153. [CrossRef]

48. Zhao, Y.; Nielsen, C.P.; Lei, Y.; McElroy, M.B.; Hao, J. Quantifying the uncertainties of a bottom-up emission inventory of anthropogenic atmospheric pollutants in China. Atmos. Chem. Phys. 2011, 10, 29075-29111. [CrossRef]

49. Alam, K.; Mukhtar, A.; Shahid, I.; Blaschke, T.; Majid, H.; Rahman, S.; Rahman, N. Source Apportionment and Characterization of Particulate Matter (PM10) in Urban Environment of Lahore. Aerosol Air Qual. Res. 2014, 14, 1851-1861. [CrossRef]

50. Chatterjee, A.; Sarkar, C.; Adak, A.; Mukherjee, U.; Ghosh, S.K.; Raha, S. Ambient air quality during Diwali festival over Kolkata-a mega-city in India. Aerosol Air Qual. Res. 2013, 13, 1133-1144. [CrossRef]

51. Liu, T.; Zhuang, G.; Huang, K.; Lin, J.; Wang, Q.; Deng, C.; Fu, J.S. A Typical Formation Mechanism of Heavy Haze-Fog Induced by Coal Combustion in an Inland City in North-Western China. Aerosol Air Qual. Res. 2017, 17, 98-107. [CrossRef]

52. Pey, J.; Querol, X.; Alastuey, A.; Forastiere, F.; Stafoggia, M. African dust outbreaks over the Mediterranean Basin during 2001-2011: $\mathrm{PM}_{10}$ concentrations, phenomenology and trends, and its relation with synoptic and mesoscale meteorology. Atmos. Chem. Phys. 2013, 13, 1395-1410. [CrossRef]

53. Wang, S.; Zhang, M.; Minguillón, M.C.; Zhang, X.; Feng, F.; Qiu, X. PM10 concentration in urban atmosphere around the eastern Tien Shan, Central Asia during 2007-2013. Environ. Sci. Pollut Res. 2015, 22, 6864-6876. [CrossRef]

54. Wang, Y.; Zhang, J.; Bai, Z.; Yang, W.; Zhang, H.; Mao, J.; Chen, L. Background concentrations of PMs in Xinjiang, West China: An estimation based on meteorological filter method and Eckhardt algorithm. Atmos. Res. 2019, 215, 141-148. [CrossRef]

55. Wang, W.; Samat, A.; Abuduwaili, J.; Ge, Y. Spatio-Temporal Variations of Satellite-Based PM 2.5 Concentrations and Its Determinants in Xinjiang, Northwest of China. Int. J. Environ. Res. Public Health 2020, 17, 2157. [CrossRef]

56. Ashraf, A.; Butt, A.; Khalid, I.; Alam, R.U.; Ahmad, S.R. Smog analysis and its effect on reported ocular surface diseases: A case study of 2016 smog event of Lahore. Atmos. Environ. 2019, 198, 257-264. [CrossRef]

57. Bourdrel, T.; Bind, M.A.; Béjot, Y.; Morel, O.; Argacha, J.F. Cardiovascular effects of air pollution. Arch. Cardiovasc. Dis. 2017, 110, 634-642. [CrossRef]

58. Guo, H.; Wang, T.; Simpson, I.J.; Blake, D.R.; Yu, X.M.; Kwok, Y.H.; Li, Y.S. Source contributions to ambient VOCs and CO at a rural site in eastern China. Atmos. Environ. 2004, 38, 4551-4560. [CrossRef]

59. Kat, S.; Shiobara, Y.; Uchiyama, K.; Miura, K.; Okochi, H.; Kobayashi, H.; Hatakeyama, S. Atmospheric CO, O3, and SO2 measurements at the summit of Mt. Fuji during the summer of 2013. Aerosol Air Qual. Res. 2016, 16, 2368-2377. [CrossRef]

60. Wang, Y.; Jia, C.; Tao, J.; Zhang, L.; Liang, X.; Ma, J.; Zhang, K. Chemical characterization and source apportionment of PM 2.5 in a semi-arid and petrochemical-industrialized city, Northwest China. Sci. Total Environ. 2016, 573, 1031-1040. [CrossRef]

61. Zhang, H.; Ying, Q. Contributions of local and regional sources of NOx to ozone concentrations in Southeast Texas. Atmos. Environ. 2011, 45, 2877-2887. [CrossRef]

62. Huang, X.; Ding, A.; Gao, J.; Zheng, B.; Zhou, D.; Qi, X.; Chi, X. Enhanced secondary pollution offset reduction of primary emissions during COVID-19 lockdown in China. Natl. Sci. Rev. 2021, 8. [CrossRef]

63. Du, W.; Zhang, Y.; Chen, Y.; Xu, L.; Chen, J.; Deng, J.; Xiao, H. Chemical characterization and source apportionment of PM 2.5 during spring and winter in the Yangtze River Delta, China. Aerosol Air Qual. Res. 2017, 17, 2165-2180. [CrossRef]

64. Chai, F.; Gao, J.; Chen, Z.; Wang, S.; Zhang, Y.; Zhang, J.; Ren, C. Spatial and temporal variation of particulate matter and gaseous pollutants in 26 cities in China. J. Environ. Sci. 2014, 26, 75-82. [CrossRef]

65. Chameides, W.L.; Fehsenfeld, F.; Rodgers, M.O.; Cardelino, C.; Martinez, J.; Parrish, D.; Wang, T. Ozone precursor relationships in the ambient atmosphere. J. Geophys. Res. Atmos. 1992, 97, 6037-6055. [CrossRef]

66. Biswas, M.S.; Ghude, S.D.; Gurnale, D.; Prabhakaran, T.; Mahajan, A.S. Simultaneous Observations of Nitrogen Dioxide, Formaldehyde and Ozone in the Indo- Gangetic Plain. Aerosol Air Qual. Res. 2019, 19, 1749-1764. [CrossRef]

67. Ghauri, B.; Lodhi, A.; Mansha, M. Development of baseline (air quality) data in Pakistan. Environ. Monit. Assess. 2007, 127, 237-252. [CrossRef]

68. Rasheed, A.; Aneja, V.P.; Aiyyer, A.; Rafique, U. Measurements and analysis of air quality in Islamabad, Pakistan. Earth Future. 2014, 2, 303-314. [CrossRef]

69. Sharma, A.; Sharma, S.K.; Mandal, T.K. Influence of ozone precursors and particulate matter on the variation of surface ozone at an urban site of Delhi, India. Sustain. Environ. Res. 2016, 26, 76-83. [CrossRef] 
70. Zhao, R.; Cui, K.P.; Wang, W.W.; Wang, L.C.; Yan, P. Atmospheric PM 2.5 and total PCDD/FsWHO2005-TEQ level: A case of Handan and Kaifeng cities, China. Aerosol Air Qual. Res. 2018, 18, 994-1007. [CrossRef]

71. Xu, G.; Jiao, L.; Zhang, B.; Zhao, S.; Yuan, M.; Gu, Y.; Tang, X. Spatial and temporal variability of the $\mathrm{PM}_{2 .} / \mathrm{PM}_{10}$ ratio in Wuhan, Central China. Aerosol Air Qual. Res. 2016, 17, 741-751. [CrossRef]

72. Huang, W.; Long, E.; Wang, J.; Huang, R.; Ma, L. Characterizing spatial distribution and temporal variation of $\mathrm{PM}_{10}$ and $\mathrm{PM}_{2.5}$ mass concentrations in an urban area of southwest China. Atmos. Pollut. Res. 2015, 6, 842-848. [CrossRef]

73. Zhao, D.; Chen, H.; Yu, E.; Luo, T. $\mathrm{PM}_{2.5} / \mathrm{PM}_{10}$ Ratios in Eight Economic Regions and Their Relationship with Meteorology in China. Adv. Meteorol. 2019, 2019, 1-15. [CrossRef]

74. Zhao, X.; Zhou, W.; Han, L.; Locke, D. Spatiotemporal variation in $\mathrm{PM}_{2.5}$ concentrations and their relationship with socioeconomic factors in China's major cities. Environ. Int. 2019, 133, 105145. [CrossRef]

75. Sugimoto, N.; Shimizu, A.; Matsui, I.; Nishikawa, M. A method for estimating the fraction of mineral dust in particulate matter using $\mathrm{PM}_{2.5}$-to- $\mathrm{PM}_{10}$ ratios. Particuology 2016, 28, 114-120. [CrossRef]

76. Zhao, Z.; Lv, S.; Zhang, Y.; Zhao, Q.; Shen, L.; Xu, S.; Jin, C. Characteristics and source apportionment of PM 2.5 in Jiaxing, China Environ. Sci. Pollut. Res. 2019, 26, 7497-7511. [CrossRef] [PubMed]

77. Yao, L.; Yang, L.; Yuan, Q.; Yan, C.; Dong, C.; Meng, C.; Wang, W. Sources apportionment of PM 2.5 in a background site in the North China Plain. Sci. Total Environ. 2016, 541, 590-598. [CrossRef] [PubMed]

78. Lodhi, A.; Ghauri, B.; Khan, M.R.; Rahman, S.; Shafique, S. Particulate matter (PM2.5) concentration and source apportionment in Lahore. J. Braz. Chem. Soc. 2009, 20, 1811-1820. [CrossRef]

79. Yu, L.; Wang, G.; Zhang, R.; Zhang, L.; Song, Y.; Wu, B.; Chu, J. Characterization and source apportionment of PM 2.5 in an urban environment in Beijing. Aerosol Air Qual. Res. 2013, 13, 574-583. [CrossRef]

80. Pu, H.; Luo, K.; Wang, P.; Wang, S.; Kang, S. Spatial variation of air quality index and urban driving factors linkages: Evidence from Chinese cities. Environ. Sci. Pollut. Res. 2017, 24, 4457-4468. [CrossRef]

81. Ye, W.F.; Ma, Z.Y.; Ha, X.Z. Spatial-temporal patterns of PM2.5 concentrations for 338 Chinese cities. Sci. Total Environ. 2018, 631, 524-533. [CrossRef] [PubMed]

82. Soleimani, M.; Amini, N.; Sadeghian, B.; Wang, D.; Fang, L. Heavy metals and their source identification in particulate matter (PM2. 5) in Isfahan City, Iran. J. Environ. Sci. 2018, 72, 166-175. [CrossRef] [PubMed]

83. Wang, M.; Zheng, S.; Nie, Y.; Weng, J.; Cheng, N.; Hu, X.; Bai, Y. Association between short-term exposure to air pollution and dyslipidemias among type 2 diabetic patients in northwest China: A population-based study. Intl. J. Environ. Res. Public Health 2018, 15, 631. [CrossRef] [PubMed] 